\title{
Trends and seasonality of river nutrients in agricultural catchments: 18 years of weekly citizen science in France
}

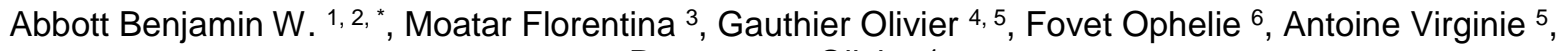 \\ Ragueneau Olivier ${ }^{4}$
}

\author{
1 Brigham Young Univ, Dept Plant \& Wildlife Sci, Provo, UT 84602 USA. \\ 2 Univ Rennes 1, CNRS, OSUR, ECOBiO, F-135045 Rennes, France. \\ ${ }^{3}$ Univ Francois Rabelais Tours, EA Geohydrosyst Continentaux 6293, Parc Grandmont, F-37200 Tours, \\ France. \\ ${ }^{4}$ Univ Bretagne Occidentale, Inst Univ Europeen Mer, LEMAR UMR CNRS UBO IRD IFREMER 6539, \\ Lab Sci Environm Marin, F-29280 Plouzane, France. \\ 5 Univ Bretagne Occidentale, Inst Univ Europeen Mer, Observ Marin UMS CNRS 3113, Brest, France. \\ 6 INRA, UMR SAS, AGROCAMPUS OUEST, F-35000 Rennes, France.
}

* Corresponding author : Benjamin W. Abbott, email address : benabbott@byu.edu

\begin{abstract}
:
Agriculture and urbanization have disturbed three-quarters of global ice-free land surface, delivering huge amounts of nitrogen and phosphorus to freshwater ecosystems. These excess nutrients degrade habitat and threaten human food and water security at a global scale. Because most catchments are either currently subjected to, or recovering from anthropogenic nutrient loading, understanding the short- and long-term responses of river nutrients to changes in land use is essential for effective management. We analyzed a never-published, 18-year time series of anthropogenic (NO3- and PO43-) and naturally derived (dissolved silica) riverine nutrients in 13 catchments recovering from agricultural pollution in western France. In a citizen science initiative, high-school students sampled catchments weekly, which ranged from 26 to $1489 \mathrm{~km}(2)$. Nutrient concentrations decreased substantially over the period of record (19 to $50 \%$ for NO3- and 14 to $80 \%$ for PO4-), attributable to regional, national, and international investment and regulation, which started immediately prior to monitoring. For the majority of catchments, water quality during the summer low-flow period improved faster than during winter high-flow conditions, and annual minimum concentrations improved relatively faster than annual maximum concentrations. These patterns suggest that water-quality improvements were primarily due to elimination of discrete nutrient sources with seasonally-constant discharge (e.g. human and livestock wastewater), agreeing with available land-use and municipal records. Surprisingly, long-term nutrient decreases were not accompanied by changes in nutrient seasonality in most catchments, attributable to persistent, diffuse nutrient stocks. Despite decreases, nutrient concentrations in almost all catchments remained well above eutrophication thresholds, and because additional improvements will depend on decreasing diffuse nutrient sources, future gains may be much slower than initial rate of recovery. These findings demonstrate the value of citizen science initiatives in quantifying long-term and seasonal consequences of changes in land management, which are necessary to identify sustainable limits and predict recovery timeframes.
\end{abstract}




\section{Graphical abstract}

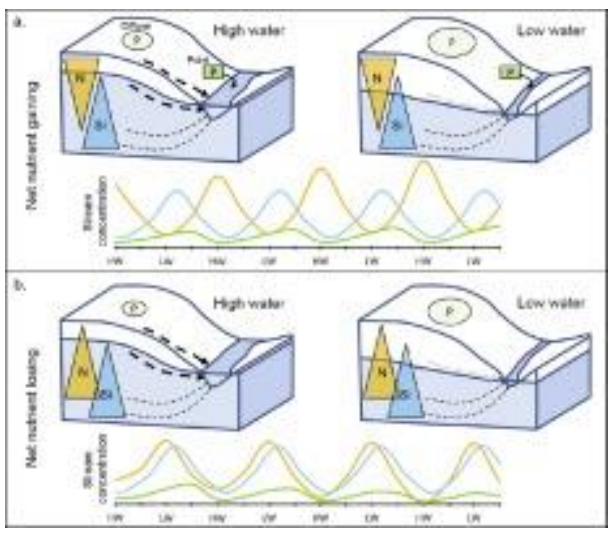

\section{Highlights}

- High schools measured $\mathrm{NO}_{3}{ }^{-}, \mathrm{PO}_{4}{ }^{3-}$, and silica weekly in 13 rivers for 18 years. of $\mathrm{NO}_{3}{ }^{-}$and $\mathrm{PO}_{4}{ }^{3-}$ primarily due to elimination of point sources Despite decline, nutrient seasonality did not change for most catchments. Concentrations remain high and future improvements may be slower than initial gains. Citizen science can produce long-term, medium-frequency water quality data.

Keywords : Eutrophication, Nitrogen, Phosphorus, Silica, Time series analysis, Citizen science 


\section{Introduction}

Nutrient pollution of freshwater and estuarine water bodies is degrading ecological functioning and ecosystem services at a global scale. Economic damage from nitrate $\left(\mathrm{NO}_{3}{ }^{-}\right)$ contamination alone is estimated to cost 0.2 to 2.3 trillion USD annually-up to $3 \%$ of the global gross domestic product (Bodirsky et al., 2014; Sutton and UNEP, 2013). In the past 50 years, global fertilizer use increased by over 500\% (Foley et al., 2011), and nitrogen and phosphorus pollution are expected to keep pace with population growth and meat consumption, increasing until the middle of the century (Canfield et al., 2010; Seitzinger et al., 2010). At the same time, human activity, primarily agriculture, has disturbed approximately three-quarters of the Earth's ice-free land surface (Ellis et al., 2010), reducing the capacity of ecosystems to buffer and process nutrient inputs (Pinay et al., 2015; Seitzinger et al., 2006; Thomas et al., 2016a). The resulting nutrient excess has contaminated groundwater aquifers (Aquilina et al., 2012; Ben Maamar et al., 2015; Jasechko et al., 2017) and increased the flux of nutrients through river systems to the sea, creating eutrophic dead zones in many lakes and estuaries, and altering biogeochemistry throughout the ocean (Diaz and Rosenberg, 2008; Howarth, 2008; Reed and Harrison, 2016). In response to this accelerating environmental crisis, governments have funded a broad range of programs to monitor and improve water quality (Andreen, 2004; Hering et al., 2010; Liu and Yang, 2012; Withers and Haygarth, 2007), but results of interventions have been mixed (Jarvie et al., 2013; Jenny et al., 2016; Wilcock et al., 2013). In many developed countries, phosphorus concentration and flux from large catchments have decreased over the last two decades, mostly due to treatment of point sources (e.g. waste water treatment plants), but $\mathrm{NO}_{3}{ }^{-}$, which is highly mobile and has many diffuse sources, has showed little change (Minaudo et al., 2015; Moatar et al., 2017). Furthermore, in small to medium catchments, where the bulk of terrestrial nutrient loading occurs (Abbott et al., 2017a; Alexander et al., 2007), trends are even less clear, with nutrient fluxes differing substantially among apparently similar catchments (Aubert et al., 2013b; Burt and Pinay, 2005; Stålnacke et al., 2003).

Two primary factors complicate the quantification of water-quality trends in small catchments. First, nutrient concentrations and fluxes through river networks vary strongly at event, seasonal, and interannual timescales (Gascuel-Odoux et al., 2010; Moatar et al., 2013; Thomas et al., 2016a), meaning that repeat measurements are necessary to characterize the overall nutrient condition of a catchment. Second, because nutrient residence times can be on the order of decades in soil, unsaturated zone, and groundwater (Howden et al., 2011; Kolbe et al., 2016; Meter et al., 2016; Sebilo et al., 2013), substantial time lags can exist before 
changes in management practice are reflected in water quality. Consequently, quantifying the effectiveness of changes in land management requires both long-term (Abbott et al., 2017a; Burt et al., 2011) and high-frequency monitoring (Abbott et al., 2016; Aubert et al., 2013a; McDonald et al., 2016; Vilmin et al., 2016). One approach to achieving this ambitious goal is to involve non-professional community members in sample collection (Bonney et al., 2014). Citizen science has been used both as a tool to extend ecological observation and a mechanism to improve the general public's engagement with science (Bonney et al., 2014; Cohn, 2008; Silvertown, 2009). Though not without limitations in data reliability and acceptance by researchers (Conrad and Hilchey, 2011), citizen science has successfully been used for a variety of projects including mapping the distribution of species, quantifying anthropogenic impacts, analyzing visual data, and monitoring water quality (Breuer et al., 2015; Gardiner et al., 2012; Kyba et al., 2013; Savage, 2012).

In this context, we analyzed a never-published, 18-year time series of riverine nutrient concentrations in 13 catchments recovering from agricultural pollution in western France. Samples collected weekly from 1998 to 2016 by volunteer high school students were analyzed for $\mathrm{NO}_{3}{ }^{-}$, phosphate $\left(\mathrm{PO}_{4}{ }^{3-}\right)$, and dissolved silica (DSi). We analyzed long-term trends and changes in seasonality, i.e. periodicity of cycles, timing of maximum and minimum concentrations, and relationships between discharge and concentration. We hypothesized generally that seasonal fluctuations in stream nutrient concentrations would depend on interactions between three factors (Fig. 1): 1. vertical and horizontal location of nutrient sources, which is a function of current and past land use and land cover, 2. seasonal changes in water flowpath and associated residence time, and 3. seasonal and long-term changes in biogeochemical nutrient retention and removal (e.g. denitrification or uptake by plants and microorganisms). Based on this hypothesis, we predicted that discharge and concentration would fluctuate asynchronously for nutrients that increase with depth (e.g. DSi, which is primarily geogenic, or $\mathrm{NO}_{3}{ }^{-}$in catchments with a legacy of groundwater pollution) and synchronously for those that decrease with depth (e.g. $\mathrm{NO}_{3}{ }^{-}$in a catchment with current excess nitrogen input; Fig. 1a). We also hypothesized that decreases in diffuse-source nutrients would more rapidly improve stream concentrations during the high-water period when shallow flowpaths with shorter residence times contribute a larger portion of discharge, but that elimination of seasonally-constant point sources (e.g. waste water effluents) would result in relatively faster nutrient decreases during low flows (Fig. 1b). We tested these predictions with a variance-partitioning approach, comparing the magnitude of seasonal, annual, and interannual changes in nutrient concentrations. 


\section{Methods}

117

118

119

120

121

122

123

124

125

\subsection{Land-use history in far western France}

The peninsula of Brittany is part of the Armorican Massif, which is underlain by crystalline bedrock and overlain by Quaternary loess and alluvial and colluvial deposits (Kolbe et al., 2016). Silty loam is the dominant soil texture. Brittany has a maritime climate with monthly average temperatures ranging from $17.5^{\circ} \mathrm{C}$ in July to $5^{\circ} \mathrm{C}$ in December and mean annual precipitation of around 1,000 mm, roughly evenly distributed through the year (Thomas et al., 2016a). While the peninsula’s many coastal catchments have relatively homogeneous climate and lithology, there is a great diversity of current and past land use, providing an ideal template to test the impact of agriculture on water quality. For example, annual $\mathrm{NO}_{3}{ }^{-}$fluxes vary from 9 to $89 \mathrm{~kg} \mathrm{~N} \mathrm{ha}^{-1} \mathrm{y}^{-1}$ among catchments (Gascuel-Odoux et al., 2010), and phosphorus fluxes vary from 0.1 to $1.4 \mathrm{~kg} \mathrm{P} \mathrm{ha}^{-1} \mathrm{yr}^{-1}$ (Delmas et al., 2015; Dupas et al., 2015), covering most of the range observed throughout western Europe (Dupas et al., 2013; Poisvert et al., 2017).

The western tip of Brittany, where our 13 study catchments are located, has a long history of intensive animal husbandry and row-crop agriculture (Fig. 2). Brittany represents only $7 \%$ of French agricultural area, but produces $55 \%, 40 \%$, and $25 \%$ of the nation's pigs, poultry, and milk, respectively (Gascuel-Odoux et al., 2010). Cow density gradually grew until 1978 when it peaked at 125 head $\mathrm{km}^{-2}$, and pig density rapidly increased from 1960 to 2005 when it reached 424 head $\mathrm{km}^{-2}$ (Poisvert et al., 2017). Total nitrogen (N) surplus, an integrative estimate of nutrient inputs and outputs at the soil level, peaked in 1989 at $143 \mathrm{~kg}$ per ha of used agricultural area (UAA) per year (Fig. 2; Poisvert et al., 2017). In the 1970s, point and non-point nutrient sources started causing frequent harmful algal blooms in estuaries and bays around the peninsula, triggered by a combination of high nutrient loading from coastal rivers, semi-enclosed bays that limit oceanic flushing of estuaries, and clear ocean water that favors rapid algal growth (Perrot et al., 2014). In response to this widespread eutrophication of inland and coastal ecosystems, a coordinated and multi-faceted series of mitigation actions and regulation measures were implemented starting in 1992 (MEDD \& Agences de l'eau, 2003). Reinforced by international and national regulation in 1998 and 2000 (Hering et al., 2010; Piot-Lepetit and Moing, 2007), millions of Euros have been invested to fund local and regional remediation projects (Regional Algal Bloom Plans, 2015; Regional Counsel, 2013). Livestock facilities have been systematically improved to reduce seepage of animal waste, application of chemical and organic fertilizer has been regulated, 
and some landscape restoration programs have been conducted to replant hedgerows and preserve wetlands (e.g. Breizh Bocage). Considerable efforts have also been made to decrease urban pollution, with installation or improvement of sewage treatment plants in many towns and cities since 2000 .

\subsection{Citizen-science program and chemical analysis}

We analyzed data from 13 stations in the Ecoflux river monitoring program (data are available at www-iuem.univ-brest.fr/ecoflux), which includes 12 small catchments of 26 to $280 \mathrm{~km}^{2}$, and 1 medium catchment of $1490 \mathrm{~km}^{2}$ (Fig. 1; Table 1). Climate and topography are relatively similar among the catchments, with annual rainfall ranging from 990 to $1395 \mathrm{~mm}$ and mean altitude from 70 to $164 \mathrm{~m}$. Long-term, continuous discharge was available for 7 of the 13 catchments, as part of regional environmental monitoring (DREAL; www.hydro.eaufrance.fr/, Table S1).

The Ecoflux program was founded in 1998 by the regional government (Conseil Général du Finistère) and the European Institute for Marine Studies (IUEM) to monitor nutrient concentrations in agricultural catchments and improve awareness of the importance of water quality for agricultural students who will be the next generation of farmers and land managers. Starting in their second year of high school, students from agricultural, natural science, and general academic tracks participated in the sampling. Following a standardized protocol, volunteer students and teachers from primarily rural high schools collected weekly water samples from the 13 stations from September 1998 to December 2015 (5 rivers) or November 2016 (8 rivers; Table 1). Students filled two acid-washed, $100 \mathrm{~mL}$, glass bottles for $\mathrm{NO}_{3}{ }^{-}$and $\mathrm{PO}_{4}{ }^{3-}$, and one $100 \mathrm{~mL}$ plastic bottle for DSi. Students filtered samples in the field to $200 \mu \mathrm{m}$ with glass fiber filters to remove particulates, and upon returning to the lab, $\mathrm{NO}_{3}{ }^{-}$ and $\mathrm{PO}_{4}{ }^{3-}$ samples were frozen and DSi samples were stored at $4{ }^{\circ} \mathrm{C}$ until analysis in one of two professional labs (details below). Volunteers from the community collected samples during school vacations. Since the program started, approximately 18 researchers, 10 graduate students, 21 adult volunteers, and 5,000 high-school students from 6 educational institutions have participated in sampling and analysis.

The IUEM analyzed all $\mathrm{PO}_{4}{ }^{3-}$ and DSi samples, and LABOCEA-Idhesa, a certified, public laboratory, analyzed all $\mathrm{NO}_{3}{ }^{-}$samples following international norms (ISO 15923-1). $\mathrm{PO}_{4}{ }^{3-}$ was quantified with a Shimadzu UV1700 spectrophotometer (SHIMADZU, Kyoto, Japan), and $\mathrm{NO}_{3}{ }^{-}$and DSi with a Technicon Auto Analyser II (SEAL Analytical, Southampton, UK). Analytical precision was $\pm 5 \%$ for $\mathrm{NO}_{3}{ }^{-}$and DSi (inline and automatic addition of reagents) and \pm 6 to $10 \%$ for $\mathrm{PO}_{4}{ }^{3-}$ (manual addition of reagents). Though few 
nutrient time series exist for comparison, Ecoflux $\mathrm{NO}_{3}{ }^{-}$concentration in river 7 showed excellent short- and long-term agreement with a professionally operated monitoring station located $4 \mathrm{~km}$ upstream (Fig. S1). The overall sampling success rate was $79 \%$ over the monitoring period (i.e. $21 \%$ of the week by river combinations were not sampled or analyzed), constituting 8,929 sets of nutrient samples. The only major gap in data occurred for river 4, which was not sampled from 2004 to 2013, due to budget and personnel constraints.

\subsection{Data analysis}

\subsubsection{Metrics of annual and interannual concentrations and loads}

For rivers with discharge data (Tables 1 and S1), we calculated monthly and annual specific discharge $\left(\mathrm{L} \mathrm{s}^{-1} \mathrm{~km}^{-2}\right)$, and the percentage of total discharge that occurs during the highest 2\% of flows (W2), a metric of flow variability (Moatar et al., 2013). To characterize annual concentrations and loads, we calculated the median concentration (C50), the flowweighted mean concentration based on discharge at the time of sampling $\left(\mathrm{C}^{*}\right)$, and the annual load using the following protocol. For each catchment and nutrient combination, we assessed the optimal method for estimating load based on the flux variability matrix, which combines hydrologic variability (i.e. W2) and concentration-discharge relationships (Meybeck and Moatar, 2012; Raymond et al., 2013). According to this matrix, the discharge-weighted concentration method was the most appropriate for the majority of the rivers and nutrients, thus the specific annual load $\left(F_{s}\right)$ was estimated as:

$$
F_{S}=\frac{k}{A} \frac{\sum_{i=1}^{n} C_{i} Q_{i}}{\sum_{i=1}^{n} Q_{i}} \bar{Q}
$$

where $C_{i}$ is the instantaneous measured concentration $\left(\mathrm{mg} \mathrm{L}^{-1}\right), Q_{i}$ is the corresponding instantaneous discharge value $\left(\mathrm{m}^{3} \mathrm{~s}^{-1}\right), \bar{Q}$ is the mean annual discharge computed from continuous flow records $\left(\mathrm{m}^{3} \mathrm{~s}^{-1}\right), A$ is the catchment area $\left(\mathrm{m}^{2}\right)$, and $k$ is a conversion factor that accounts for the sampling period ( 1 week in this case). An advantage of this approach is that uncertainty intervals can be calculated based on the discharge and concentration variabilities for a given sampling frequency, and estimates can be corrected according to the associated bias (Moatar et al., 2013). We calculated Pearson correlations (r) to test for relationships between median stream nutrient concentrations and modeled nitrogen $(\mathrm{N})$ and phosphorus (P) surplus from agriculture, estimated with land use data and a wide range of $\mathrm{N}$ and P processes (Dupas et al., 2013; Schoumans et al., 2009). For example, the $\mathrm{N}$ module of the model included symbiotic fixation, atmospheric deposition, application of synthetic and organic fertilizers, volatilization, and hydrologic N export (Dupas et al., 2013). For the rivers 
with discharge data, pairwise linear regressions between C50, C*, and annual load were used to assess whether median concentrations were good predictors of annual loads.

\subsubsection{Time series analysis of nutrient concentrations}

We modeled the amplitude, frequency, and phase of nutrient concentrations for all catchments except river 4 (excluded because a gap in measurements from 2004 to 2013). First, we calculated long-term trends with simple linear regression to detrend time series with significant interannual slopes, creating stationary series for all subsequent analyses (Legendre and Gauthier, 2014). We then used distance-based Moran’s Eigenvector Maps (dbMEMs; Borcard et al., 1992; Dray et al., 2006) to model frequency and amplitude of fluctuations for nutrient concentrations. This method yields sine wave variables at multiple frequencies, similar to those obtained from Fourrier transformation, allowing partitioning of overall variance between multiple timescales. The time variables are the result of a principal coordinates analysis (PCoA) of the temporal distance matrix. We computed dbMEMs from the oldest to the most recent sampling date for each river-nutrient combination. We analyzed the positive temporal structures of the dataset using a lag of 1 week as the threshold for determining neighbors, and performed multiple linear regressions with all positive dbMEMs and the associated nutrient concentrations. We used forward selection of explanatory variables to thin significant models. Reduced models were then split in 3 sub-models relating to different timescales: long-term (longer than 64 weeks), seasonal (40 to 64 weeks), and short-term (less than 40 weeks), by grouping and re-computing selected dbMEMS according to their wavelength. We then determined the portion of overall variance explained by each sub-model with hierarchical partitioning of variance, which ranks sub-models according to goodness of fit with temporal structure, and in case of overlap in explained variance, gives precedence to the longer timescale (Legendre et al., 2012). We used the adjusted coefficient of determination (adj- $\mathrm{R}^{2}$ ) as an unbiased measure of goodness of fit for all models (Ohtani, 2004).

To test if rate of recovery was associated with initial anthropogenic pressure, we correlated initial concentration (intercept of the linear model) with percent change (based on linear slopes) for each nutrient, using the regressions calculated during the detrending procedure described at the beginning of this section. To allow comparison among nutrients, we calculated linear slopes for both raw and scaled data (after subtracting the mean and dividing by the standard deviation; SD). To test our prediction that elimination of point sources would cause relatively larger nutrient decreases during low flow, while decreases in diffuse sources would result in larger high-flow nutrient decreases (Fig. 1), we compared 
slopes of interannual trends for mean August concentrations (low flow) and December concentrations (high flow). Additionally, to assess whether annual maximum or minimum concentrations changed faster, we compared slopes of interannual trends for the mean of the five highest and lowest values from each year for each nutrient. We evaluated the significance of long-term trends with Mann Kendall tests and compared parametric detrended slopes with Theil-Sen slope estimates determined following the Siegel method (Komsta, 2005). While uniform land-use and nutrient input data did not exist at these spatial and temporal scales, we re-extracted annual N surplus for each catchment from Poisvert et al., (2017), and analyzed all available departmental data on phosphorus loading from livestock to assess changes in nonpoint nutrient sources prior and during the study period (i.e. 1988, 2000, and 2010). To quantify changes in point sources, we compiled records from wastewater treatment plants and industrial sites (e.g. slaughterhouses and food processing plants) for 1998, 2001-2006, and 2015. The compiled data represented 52 to $100 \%$ (mean $=80 \%$ ) of the area for 11 out of the 13 catchments, providing a robust estimate of relative changes in point and non-point nutrient inputs.

All analyses were conducted in R (R Core Team, 2016) with the vegan, adespatial, and ggplot2 packages (Dray et al., 2017; Oksanen et al., 2007; Wickham, 2009), with additional functions from Legendre and Gauthier (2014).

\section{Results}

\subsection{Hydrologic and stoichiometric differences among rivers}

For the 7 rivers with long-term hydrologic monitoring, mean annual specific discharge (1966-2016) varied less than a factor of 2 (12.2 to $23.5 \mathrm{~L} \mathrm{~s}^{-1} \mathrm{~km}^{-2}$; Table 1). Minimum monthly specific discharge was more variable (2.5 to $7.0 \mathrm{~L} \mathrm{~s}^{-1} \mathrm{~km}^{-2}$ ), with some catchments showing influence from groundwater (e.g. river 10) or reservoirs (e.g. river 7) during low flows (Table 1). Hydrologic variability was highest for rivers 6 and 5, which had flashy hydrographs (W2 > 10\%), and lowest for the four northeastern rivers 10-13 (W2 between 7.2 and $8.4 \%$ ), which showed more buffered discharge during floods. All but 1 catchment (river 1) had modeled $\mathrm{N}$-surplus greater than $30 \mathrm{~kg} \mathrm{~N}^{-1}$ year $^{-1}$, and 3 catchments exceeded $60 \mathrm{~kg}$ $\mathrm{N} \mathrm{ha}^{-1}$ year $^{-1}$ (rivers 8-10). P surplus was moderate to high, ranging from 19 to $32 \mathrm{~kg} \mathrm{P} \mathrm{ha}^{-1}$ year ${ }^{-1}$. N surplus was not correlated with median $\mathrm{NO}_{3}{ }^{-}$concentration $(\mathrm{p}>0.05)$, but was correlated with median $\mathrm{PO}_{4}{ }^{3-}$ concentration $(\mathrm{r}=0.69, \mathrm{p}<0.05)$, potentially due to differences in nutrient retention and removal capacity among the catchments. Modeled P surplus was not correlated with any median nutrient concentrations ( $\mathrm{p}>0.05)$. 
There was substantial variation in concentration among the rivers for both anthropogenic $\left(\mathrm{PO}_{4}{ }^{3-}\right.$ and $\left.\mathrm{NO}_{3}{ }^{-}\right)$and naturally-occurring (DSi) nutrients, with the median concentration over the period of record varying approximately 4-fold among rivers for $\mathrm{NO}_{3}{ }^{-}$, 3-fold for DSi, and 12-fold for $\mathrm{PO}_{4}{ }^{3-}$ (Table 2). Median DSi and $\mathrm{NO}_{3}{ }^{-}$concentrations among rivers were positively correlated $(\mathrm{r}=0.67, \mathrm{p}<0.001)$ as were median $\mathrm{NO}_{3}{ }^{-}$and $\mathrm{PO}_{4}{ }^{3-}(\mathrm{r}=$ 0.57, $\mathrm{p}<0.05$ ), but DSi and $\mathrm{PO}_{4}{ }^{3-}$ were not correlated ( $\left.\mathrm{p}>0.05\right)$, and $\mathrm{N}: \mathrm{P}$ and DSi:P ratios varied widely (Fig. S2). The pairwise linear regressions between concentration and load parameters showed that flow-weighted means $\left(\mathrm{C}^{*}\right)$ were strongly associated with median concentrations (C50; $\mathrm{R}^{2}>0.86, \mathrm{p}<0.01$ for all parameters; Table 2). Slopes were near 1 for DSi and $\mathrm{NO}_{3}{ }^{-}$(0.92 and 0.82, respectively) but less than 1 for $\mathrm{PO}_{4}{ }^{3-}(0.66)$, indicating that median concentration overestimated flow-weighted mean for $\mathrm{PO}_{4}{ }^{3-}$, due to systematic dilution during high flow events. $\mathrm{C} 50$ and $\mathrm{C}^{*}$ were good predictors of annual loads for $\mathrm{NO}_{3}{ }^{-}$and $\mathrm{PO}_{4}{ }^{3-}$ ( $\mathrm{R}^{2}$ between 0.77 and 0.89 ) but not for DSi $\left(\mathrm{R}^{2}=0.43\right.$ and 0.38 for C50 and $\mathrm{C}^{*}$, respectively).

\subsection{Long-term trends in nutrient concentrations}

Between 1998 and 2015, point-source nutrient inputs at the departmental level decreased $91 \%$ for $\mathrm{N}$ and $86 \%$ for P due to construction of wastewater treatment plants and regulation of industrial discharge (Table S2). Non-point nutrient inputs peaked in 1987 and then decreased an average of $59 \%(\mathrm{SD}=8.7)$ for $\mathrm{N}$ by 2015 and $65 \%(\mathrm{SD}=6.1)$ for $\mathrm{P}$ by 2010 for the catchments with available data (Fig. S3). Between 1999 and 2016, $\mathrm{NO}_{3}{ }^{-}$ concentration decreased significantly $(\mathrm{p}<0.05)$ for all catchments, $\mathrm{PO}_{4}{ }^{3-}$ decreased for all but 1 catchment, and DSi showed little or no change (Figs. 3 and 4; Table S3). The parametric regression slopes and the Theil-Sen slope estimates were strongly correlated for all nutrients ( $\mathrm{r}=0.97,0.95$, and 0.89 , for $\mathrm{NO}_{3}{ }^{-}, \mathrm{PO}_{4}{ }^{3-}$, and DSi, respectively), but the Theil-Sen slopes were consistently shallower for $\mathrm{PO}_{4}{ }^{3-}$ (Table S3), suggesting that changes in extreme values account for much of the long-term decreases. The regression slopes of scaled $\mathrm{PO}_{4}{ }^{3-}$ and $\mathrm{NO}_{3}{ }^{-}$ time series were similar, ranging from $-0.310^{-4}$ to $-2.410^{-4}$ (Fig. S4; Table S3), representing mean 1998 to 2016 decreases of $34 \%(\mathrm{SD}=8.8)$ for $\mathrm{NO}_{3}{ }^{-}$and $46 \%(\mathrm{SD}=21)$ for $\mathrm{PO}_{4}{ }^{3-}$ (Fig. 4). For $\mathrm{PO}_{4}{ }^{3-}$, the greatest decreases occurred in rivers with highest initial $\mathrm{PO}_{4}{ }^{3-}$ concentration $(\mathrm{r}=0.70, \mathrm{p}<0.01)$, but changes in $\mathrm{NO}_{3}{ }^{-}$and DSi were not correlated with initial concentrations ( $p>0.1$; Fig. 4). For the 7 rivers with discharge data, annual nutrient fluxes followed the same general pattern as concentrations (decreasing for $\mathrm{NO}_{3}{ }^{-}$and $\mathrm{PO}_{4}{ }^{3-}$; no trend for DSi), but were more variable due to inter-annual differences in river discharge (Fig. 6).

Annual minimum concentrations decreased faster than maximum concentrations for 77 and $92 \%$ of catchments for $\mathrm{NO}_{3}{ }^{-}$and $\mathrm{PO}_{4}{ }^{3-}$, respectively, and minimum and maximum 
trends were only correlated with each other for $\mathrm{PO}_{4}{ }^{3-}(\mathrm{r}=0.58, \mathrm{p}<0.05$; Fig. 5a). Low-flow concentrations (August) decreased faster than high-flow concentrations (December) for 62 and $69 \%$ of catchments for $\mathrm{NO}_{3}{ }^{-}$and $\mathrm{PO}_{4}{ }^{3-}$, respectively, and low-flow and high-flow trends were only correlated with each other for $\mathrm{NO}_{3}{ }^{-}(\mathrm{r}=0.63, \mathrm{p}<0.05$; Fig. 5b). Furthermore, several catchments had extreme differences in long-term low-flow and high-flow trends of DSi and $\mathrm{PO}_{4}{ }^{3-}$ (e.g. in river 5 there was a strongly increasing trend for DSi during low flows, driven by extreme low-flow conditions in 2011, but there was no trend for high flows; Fig. 5b).

\subsection{Partitioning variance between timescales}

Modeled fluctuations in nutrients showed good agreement with measured values (Fig. 7), though the proportion of explained variance varied by nutrient and river (Table 3). Final models explained 52 to $85 \%$ of the temporal variation in $\mathrm{NO}_{3}{ }^{-}$concentration, 20 to $90 \%$ for $\mathrm{PO}_{4}{ }^{3-}$, and 57 to $87 \%$ for DSi (Table 3). River 11 was particularly well explained by temporal variables for all nutrients $\left(68,90\right.$, and $75 \%$ for $\mathrm{NO}_{3}{ }^{-}, \mathrm{PO}_{4}{ }^{3-}$, and $\mathrm{DSi}$, respectively) while river 1 had the poorest fits $\left(54,28\right.$, and $59 \%$ of overall variance explained for $\mathrm{NO}_{3}{ }^{-}, \mathrm{PO}_{4}{ }^{2-}$ and $\mathrm{DSi}$, respectively; Table 3).

Short-term timescales ( $<40$ weeks) tended to account for the smallest portion of variance across nutrients, explaining less than $30 \%$ of the variation in concentrations excepted for DSi in rivers 7 and 12 (38\%). For $\mathrm{NO}_{3}{ }^{-}$, the long-term component (> 64 weeks) explained the largest portion of variance for all rivers except river 5 , where $52 \%$ of variation was explained by seasonal fluctuations. For $\mathrm{PO}_{4}{ }^{3-}$, the relative importance of seasonal and long-term fluctuations depended on the river (Table 3). For DSi, which showed little to no long-term trend, seasonal fluctuation (40 to 64 weeks) explained the largest proportion of variation for most rivers.

\subsection{Contrasting seasonal cycles}

For the rivers where seasonal variation accounted for at least $10 \%$ of overall variance, synchrony between concentration and discharge differed by river and nutrient (Fig. 8). For $\mathrm{NO}_{3}{ }^{-}, 3$ rivers showed synchronous fluctuations (positive concentration-discharge relationship) and 4 rivers showed asynchronous fluctuations (Fig. 9a,b). Contrary to our hypothesis (Fig. 1), the synchronous catchments tended to have lower initial and median $\mathrm{NO}_{3}{ }^{-}$ concentrations compared to asynchronous catchments, and there was no apparent relationship with magnitude of long-term decrease and fluctuation type (Figs. 4 and 9). For $\mathrm{PO}_{4}{ }^{3-}$ and DSi, all the fluctuations were asynchronous except for river 5 , which had a hydrologically synchronous cycle for DSi (Fig. 9c-e). 
The relative amplitude of seasonal fluctuations was generally higher for $\mathrm{PO}_{4}{ }^{3-}$ (180$300 \%$ of the C50) than for $\mathrm{NO}_{3}{ }^{-}(100-170 \%)$ and DSi (ca. $20 \%$ ), with the exception of river 5 , which had higher relative amplitude of seasonal fluctuations for both $\mathrm{NO}_{3}{ }^{-}$(380 \%) and DSi (180 \%) than $\mathrm{PO}_{4}{ }^{3-}$ (70 \%; Figs. 8 and 9). For most catchments, DSi maximum concentration occurred later in the season than $\mathrm{NO}_{3}{ }^{-}$maximum (Fig. 8).

Most catchments showed the same concentration-discharge relationship for each nutrient over the period of record (i.e. each catchment remained either asynchronous or synchronous), but there was an increase through time in variance among asynchronous catchments in the periodicity of seasonal fluctuations for both $\mathrm{NO}_{3}{ }^{-}$and $\mathrm{PO}_{4}{ }^{3-}$, primarily after 2008 (Fig. 9a,c). Changes in the periodicity and timing of $\mathrm{PO}_{4}{ }^{3-}$ fluctuations in rivers 7 and 13 were particularly marked, with both rivers experiencing a shift in minimum $\mathrm{PO}_{4}{ }^{3-}$ concentration from winter to early spring, and a shift in $\mathrm{PO}_{4}{ }^{3-}$ maximum from summer to fall or winter (Figs. S5 and S6).

\section{Discussion}

\subsection{Using seasonality and interannual trends to infer nutrient legacies}

Because river flow integrates water from multiple flowpaths with a distribution of residence times, river chemistry is the product of overlapping historical inputs and reaction rates, which are spatially distributed and temporally weighted within the catchment (Abbott et al., 2016; Gu et al., 2017; Meter and Basu, 2015). We hypothesized that the seasonality of nutrient concentrations could reveal net nutrient balance at the catchment scale and that differences in interannual trajectories of low- and high-water nutrient concentrations could indicate whether changes in point or diffuse nutrient sources accounted for improvements (Fig. 1). All of the catchments in our study showed decreasing trends for anthropogenic nutrients $\left(\mathrm{NO}_{3}{ }^{-}\right.$and $\mathrm{PO}_{4}{ }^{3-}$ ) starting from the beginning of the record in 1998. These water quality improvements can be attributed to better land management rather than less intensive agricultural land use, because the number of livestock continued to increase through 2005 (Fig. 2; Poisvert et al., 2017). In line with our predictions for net nutrient losing catchments with bottom-loaded nutrients (Fig. 1b), most catchments showed asynchronous nutrientdischarge fluctuations and delayed arrival of DSi peaks compared to $\mathrm{NO}_{3}{ }^{-}$, though we recognize that both pre- and post-intervention monitoring is necessary to more definitively test the link between nutrient seasonality and catchment-scale net nutrient balance.

Contrary to observational and modeling studies that concluded increasing agricultural pressure results in chemostatic nutrient behavior due to homogenization of nutrient sources 
and saturation of removal capacity (Dupas et al., 2016; Moatar et al., 2017; Musolff et al., 2016), we found that catchments with lower nutrients tended to show less temporal variability and synchronous fluctuation of $\mathrm{NO}_{3}{ }^{-}$(Figs. 8 and 9). The synchronous seasonal cycles observed in rivers 3, 5, and 6 could be explained by 1 . top-loaded $\mathrm{NO}_{3}{ }^{-}$profiles (Fig. 1a) maintained by autotrophic denitrification deeper in the aquifer or sustained $\mathrm{NO}_{3}{ }^{-}$loading (Fovet et al., 2015), or 2. enhanced biological uptake in the catchment or river during summer low flows. Both denitrification and uptake are more likely to affect bulk fluxes when concentrations are low due to mass balance and stoichiometric constraints (Abbott et al., 2017a; Pinay et al., 2015), supporting the hypothesis of biological regulation of $\mathrm{NO}_{3}{ }^{-}$ concentration during low flows in the less eutrophic catchments (Moatar et al., 2017). In addition to land-use legacy, hydrologic or biogeochemical differences among catchments can influence nutrient-discharge synchrony. In agricultural catchments, both synchronous (Álvarez-Cabria et al., 2016; Aubert et al., 2013b; Bowes et al., 2009; Dupas et al., 2016; Exner-Kittridge et al., 2016; Mellander et al., 2014; Minaudo et al., 2015) and asynchronous (Fovet et al., 2015; Martin et al., 2004; Oulehle et al., 2015) discharge- $\mathrm{NO}_{3}{ }^{-}$ relationships have been observed. However, it remains unclear how much of these patterns are due to current and past nitrogen loading versus differences in hydrologic characteristics and inherent resilience to nutrient loading. For $\mathrm{PO}_{4}{ }^{3-}$, asynchronous fluctuations appear to be the rule in disturbed ecosystems, likely associated with dilution of point sources during high flows and enhanced release of reactive phosphorus during warm periods (Aguilera et al., 2015; Bowes et al., 2009; Duan et al., 2012; Minaudo et al., 2015). DSi seasonality also appears to be consistently asynchronous with discharge, due to dilution and seasonal differences in uptake by diatoms (Bowes et al., 2009; House et al., 2001; Moatar et al., 2017; Neal et al., 2000). DSi concentration in the sole synchronous river in our study (river 5) is likely due to its large artificial reservoir, which could increase summer uptake or delay delivery of dilute winter water. Ultimately, the utility of nutrient seasonality as a proxy of net nutrient balance needs to be tested in a broader set of anthropogenic, topographic, and climatic contexts where land use and land management can be better constrained (Dupas et al., 2017; Meter and Basu, 2015; Musolff et al., 2016; Worrall et al., 2015). While such datasets are currently rare, increased efforts to compare catchments and synthesize land use and water chemistry are critical to teasing apart the role of loading legacies, hydrology, and biological dynamics (Abbott et al., 2017b; Dupas et al., 2016; Thomas et al., 2016b).

\subsection{Stable seasonality despite deep decreases}


Despite large decreases in point and diffuse nutrient inputs and annual river concentrations, seasonality of nutrient fluctuations remained stable across the time series, except for $\mathrm{PO}_{4}{ }^{3-}$ in two catchments. One reason for this stability in seasonality may be that the relatively smaller decreases in diffuse nutrient inputs may not be have fully propagated through soils and aquifers to alter concentration-discharge relationships (Dupas et al., 2016; Meter et al., 2016; Musolff et al., 2015). Groundwater residence time in similar catchments in the region varies from 35 to 74 years (Kolbe et al., 2016), meaning that elimination of diffuse nutrient sources could take decades before influencing river chemistry. Conversely, the large decrease of discrete nutrient sources immediately affected nutrient concentrations, resulting in relatively larger low-flow improvements in water quality as predicted. The greater relative decreases in $\mathrm{PO}_{4}{ }^{3-}$, which has primarily discrete sources, compared to $\mathrm{NO}_{3}{ }^{-}$, which is mobile and often diffuse, was also in line with large point-source reductions (Bouza-Deaño et al., 2008; Minaudo et al., 2015; Moatar et al., 2017). In contrast to changes in diffuse sources, which could flip the catchment-scale vertical distribution of nutrients and concentrationdischarge relationships (Dupas et al., 2016), point-source reduction is expected to decrease low-flow peak concentrations but not fundamentally change seasonality (Fig. 1), explaining the observed stability in seasonal patterns. While the two catchments that showed evidence of shifting $\mathrm{PO}_{4}{ }^{3-}$ seasonality (rivers 7 and 13) did not have the highest initial $\mathrm{PO}_{4}{ }^{3-}$ concentrations, they did have the highest $\mathrm{P}$ surplus and were among those that showed the greatest relative $\mathrm{PO}_{4}{ }^{3-}$ decrease (Fig. 4; Table 1). In these two catchments, decreases in both point and diffuse phosphorus sources could have delayed peak concentrations from summer to fall or winter, when the soils are first hydrologically connected to the stream network after the dry period (Dupas et al., 2015; Gu et al., 2017; Thomas et al., 2016a).

Changes in $\mathrm{NO}_{3}{ }^{-}$and $\mathrm{PO}_{4}{ }^{3-}$ seasonality have been observed in long time series, due to both anthropogenic and environmental trends (Minaudo et al., 2015; Worrall et al., 2015; Zhang et al., 2015). For example, from 1868-2009, peak concentration of $\mathrm{NO}_{3}{ }^{-}$concentration in the Thames River (U.K.) shifted several times from late winter to early or late spring, independent of interannual changes in concentration, while the timing of annual minimum concentration followed timing of minimum stream flow (Worrall et al., 2015). Additionally, the amplitude of $\mathrm{PO}_{4}{ }^{3-}$ and $\mathrm{NO}_{3}{ }^{-}$seasonal fluctuations have generally decreased over the last 30 years in the Loire River (France) as nutrient concentrations have fallen (Minaudo et al., 2015). Finally, timing of seasonal maximum and minimum nutrient concentrations has remained relatively stable for most tributaries of the Chesapeake Bay (U.S.A.) since 1980, except the Susquehanna River, which has experienced major shifts in the timing and 
magnitude of nutrient seasonality due to dam removal (Zhang et al., 2015). Together these examples suggest that new metrics of nutrient seasonality should be integrated into analyses of water quality time series.

\subsection{Citizen science as a means and an end}

The Ecoflux program is an example of how citizen science can sustain long-term, medium-frequency water quality monitoring, allowing the quantification of seasonal nutrient trajectories on decadal timescales. While less obvious than the quantitative data products generated by this program, a secondary benefit is the personal impact on awareness and mentality of the thousands of students and volunteers who have participated over the years. How the general public perceives and values aquatic ecosystems directly influences how they are managed by political and administrative entities (Linton, 2014; Schmidt, 2014). In this sense, participatory water quality monitoring is not only a means of generating understanding of how water and nutrients propagate through catchments; it is a mechanism to improve water quality itself.

Because water quality recovery trajectories are typically far slower than ambitious improvement programs (Hering et al., 2010), maintaining interest and morale of stakeholders is central to successful protection and rehabilitation of aquatic ecosystems. Even when water quality does not immediately respond to substantial investment and change in land management, citizen science efforts such as the Ecoflux program are one way to deliver a tangible reward for these efforts by providing quality educational experiences for the children of involved land managers and users (e.g. farmers, politicians, special interest groups etc.). New sensors now allow high-frequency monitoring of water quality, opening up new horizons for detailed, mechanistic study of in-stream and catchment processes (Ruhala and Zarnetske, 2017; Tunaley et al., 2016). However, these sensors are expensive and difficult to maintain. Though technological solutions are always in vogue, we believe there are substantial ancillary benefits of low-tech, participatory monitoring approaches. Ultimately, high-frequency and citizen science approaches are extremely complimentary, but when budget constraints put them in competition, the built-in engagement and education associated with citizen science, as well as its low cost, are strong reasons to advocate for wider implementation of this strategy.

\section{Conclusions}

We used 18 years of weekly nutrient data collected by high-school students and community volunteers to assess how improvements in land management affect interannual trends and seasonality of nutrient concentrations. Decreases in nutrient concentrations were 
apparent from the beginning of the monitoring period, demonstrating that changes in land management can initially improve riverine nutrient concentrations at the catchments scale. There were substantial decreases in annual and seasonal $\mathrm{NO}_{3}{ }^{-}$and $\mathrm{PO}_{4}{ }^{3-}$ concentrations, with more pronounced decreases in annual minimum nutrient concentrations and during low flows, in line with historical observations that improvements are primarily due to the elimination of point sources. However, nutrient concentrations in nearly all rivers remained well above regulatory limits (Hering et al., 2010; MEDD \& Agences de l'eau, 2003) and thresholds needed to reduce inland and coastal eutrophication (Dodds et al., 1998; Perrot et al., 2014), suggesting that future gains in water quality will depend on addressing diffuse nutrient sources, which remains challenging. Seasonal covariation of discharge and nutrient concentrations was largely asynchronous across the time series, indicating that dilution dynamics are dominant and that biological activity only affects $\mathrm{NO}_{3}{ }^{-}$flux in the least polluted catchments. This project demonstrates that when institutional support and funding are available, citizen science initiatives can produce high quality data on decadal timescales and improve public engagement with socioecological issues.

\section{Acknowledgements}

We thank the regional government (Conseil Général du Finistère) and the European Institute for Marine Studies (IUEM) for supporting the Ecoflux program. We are grateful to the two anonymous reviewers, whose constructive critiques improved the manuscript. Abbott was supported by the European Union's Seventh Framework Program for research, technological development and demonstration under grant agreement no. 607150 (FP7-PEOPLE-2013ITN-INTERFACES - Ecohydrologic interfaces as critical hotspots for transformations of ecosystem exchange fluxes and biogeochemical cycling). All nutrient data are freely available at https://www-iuem.univ-brest.fr/ecoflux/observation/acces-aux-donnees. 
Abbott, B.W., Baranov, V., Mendoza-Lera, C., Nikolakopoulou, M., Harjung, A., Kolbe, T., Balasubramanian, M.N., Vaessen, T.N., Ciocca, F., Campeau, A., Wallin, M.B., Romeijn, P., Antonelli, M., Gonçalves, J., Datry, T., Laverman, A.M., de Dreuzy, J.-R., Hannah, D.M., Krause, S., Oldham, C., Pinay, G., 2016. Using multi-tracer inference to move beyond singlecatchment ecohydrology. Earth-Sci. Rev. 160, 19-42. https://doi.org/10.1016/j.earscirev.2016.06.014

Abbott, B.W., Gruau, G., Zarnetske, J.P., Moatar, F., Barbe, L., Thomas, Z., Fovet, O., Kolbe, T., Gu, S., Pierson-Wickmann, A.-C., Davy, P., Pinay, G., 2017a. Unexpected stability and synchrony of water quality in stream networks. Ecol. Lett. Accepted. https://doi.org/10.1111/ele.12897

Abbott, B.W., Pinay, G., Burt, T.P., 2017b. Protecting Water Resources Through a Focus on Headwater Streams. Eos Trans. Am. Geophys. Union EO076897. https://doi.org/10.1029/2017EO076897

Aguilera, R., Marcé, R., Sabater, S., 2015. Detection and attribution of global change effects on river nutrient dynamics in a large Mediterranean basin. Biogeosciences 12, 4085-4098. https://doi.org/10.5194/bg-12-4085-2015

Alexander, R.B., Boyer, E.W., Smith, R.A., Schwarz, G.E., Moore, R.B., 2007. The Role of Headwater Streams in Downstream Water Quality. J. Am. Water Resour. Assoc. 43, 41-59. https://doi.org/10.1111/j.1752-1688.2007.00005.x

Álvarez-Cabria, M., Barquín, J., Peñas, F.J., 2016. Modelling the spatial and seasonal variability of water quality for entire river networks: Relationships with natural and anthropogenic factors. Sci. Total Environ. 545-546, 152-162. https://doi.org/10.1016/j.scitotenv.2015.12.109

Andreen, W.L., 2004. Water Quality Today - Has the Clean Water Act Been a Success? (SSRN Scholarly Paper No. ID 554803). Social Science Research Network, Rochester, NY.

Aquilina, L., Vergnaud-Ayraud, V., Labasque, T., Bour, O., Molénat, J., Ruiz, L., de Montety, V., De Ridder, J., Roques, C., Longuevergne, L., 2012. Nitrate dynamics in agricultural catchments deduced from groundwater dating and long-term nitrate monitoring in surface- and groundwaters. Sci. Total Environ. 435-436, 167-178. https://doi.org/10.1016/j.scitotenv.2012.06.028

Aubert, A.H., Gascuel, C., Merot, P., 2013a. Annual hysteresis of water quality: A method to analyse the effect of intra- and inter-annual climatic conditions. J. Hydrol. 478, 29-39. https://doi.org/10.1016/j.jhydrol.2012.11.027

Aubert, A.H., Gascuel-Odoux, C., Gruau, G., Akkal, N., Faucheux, M., Fauvel, Y., Grimaldi, C., Hamon, Y., Jaffrézic, A., Lecoz-Boutnik, M., Molénat, J., Petitjean, P., Ruiz, L., Merot, P., 2013b. Solute transport dynamics in small, shallow groundwater-dominated agricultural catchments: insights from a high-frequency, multisolute $10 \mathrm{yr}$-long monitoring study. Hydrol. Earth Syst. Sci. 17, 1379-1391. https://doi.org/10.5194/hess-17-1379-2013

Ben Maamar, S., Aquilina, L., Quaiser, A., Pauwels, H., Michon-Coudouel, S., Vergnaud-Ayraud, V., Labasque, T., Roques, C., Abbott, B.W., Dufresne, A., 2015. Groundwater Isolation Governs Chemistry and Microbial Community Structure along Hydrologic Flowpaths. Front. Microbiol., $\begin{array}{llll}\text { Microbiological Chemistry and Geomicrobiology 6, } 1457 . & \end{array}$ https://doi.org/10.3389/fmicb.2015.01457

Bodirsky, B.L., Popp, A., Lotze-Campen, H., Dietrich, J.P., Rolinski, S., Weindl, I., Schmitz, C., Müller, C., Bonsch, M., Humpenöder, F., Biewald, A., Stevanovic, M., 2014. Reactive nitrogen requirements to feed the world in 2050 and potential to mitigate nitrogen pollution. Nat. Commun. 5. https://doi.org/10.1038/ncomms4858

Bonney, R., Shirk, J.L., Phillips, T.B., Wiggins, A., Ballard, H.L., Miller-Rushing, A.J., Parrish, J.K., 2014. Next Steps for Citizen Science. Science 343, 1436-1437. https://doi.org/10.1126/science.1251554

Borcard, D., Legendre, P., Drapeau, P., 1992. Partialling out the Spatial Component of Ecological Variation. Ecology 73, 1045-1055. https://doi.org/10.2307/1940179 
Bouza-Deaño, R., Ternero-Rodríguez, M., Fernández-Espinosa, A.J., 2008. Trend study and assessment of surface water quality in the Ebro River (Spain). J. Hydrol. 361, 227-239. https://doi.org/10.1016/j.jhydrol.2008.07.048

Bowes, M.J., Smith, J.T., Neal, C., 2009. The value of high-resolution nutrient monitoring: A case study of the River Frome, Dorset, UK. J. Hydrol. 378, 82-96. https://doi.org/10.1016/j.jhydrol.2009.09.015

Breuer, L., Hiery, N., Kraft, P., Bach, M., Aubert, A.H., Frede, H.-G., 2015. HydroCrowd: a citizen science snapshot to assess the spatial control of nitrogen solutes in surface waters. Sci. Rep. 5, 16503. https://doi.org/10.1038/srep16503

Burt, T.P., Howden, N.J.K., Worrall, F., McDonnell, J.J., 2011. On the value of long-term, lowfrequency water quality sampling: avoiding throwing the baby out with the bathwater. Hydrol. Process. 25, 828-830. https://doi.org/10.1002/hyp.7961

Burt, T.P., Pinay, G., 2005. Linking hydrology and biogeochemistry in complex landscapes. Prog. Phys. Geogr. 29, 297-316. https://doi.org/10.1191/0309133305pp450ra

Canfield, D.E., Glazer, A.N., Falkowski, P.G., 2010. The Evolution and Future of Earth's Nitrogen Cycle. Science 330, 192-196. https://doi.org/10.1126/science.1186120

Cohn, J.P., 2008. Citizen Science: Can Volunteers Do Real Research? BioScience 58, $192-197$. https://doi.org/10.1641/B580303

Conrad, C.C., Hilchey, K.G., 2011. A review of citizen science and community-based environmental monitoring: issues and opportunities. Environ. Monit. Assess. 176, 273-291. https://doi.org/10.1007/s10661-010-1582-5

Delmas, M., Saby, N., Arrouays, D., Dupas, R., Lemercier, B., Pellerin, S., Gascuel-Odoux, C., 2015. Explaining and mapping total phosphorus content in French topsoils. Soil Use Manag. 31, 259-269. https://doi.org/10.1111/sum.12192

Diaz, R.J., Rosenberg, R., 2008. Spreading Dead Zones and Consequences for Marine Ecosystems. Science 321, 926-929. https://doi.org/10.1126/science.1156401

Dodds, W.K., Jones, J.R., Welch, E.B., 1998. Suggested classification of stream trophic state: distributions of temperate stream types by chlorophyll, total nitrogen, and phosphorus. Water Res. 32, 1455-1462.

Dray, S., Blanchet, G., Borcard, D., Guenard, G., Jombart, T., Larocque, G., Legendre, P., Madi, N., Wagner, H., 2017. Multivariate Multiscale Spatial Analysis. R package version 0.0-8.

Dray, S., Legendre, P., Peres-Neto, P.R., 2006. Spatial modelling: a comprehensive framework for principal coordinate analysis of neighbour matrices (PCNM). Ecol. Model. 196, 483-493. https://doi.org/10.1016/j.ecolmodel.2006.02.015

Duan, S., Kaushal, S.S., Groffman, P.M., Band, L.E., Belt, K.T., 2012. Phosphorus export across an urban to rural gradient in the Chesapeake Bay watershed. J. Geophys. Res. Biogeosciences 117, G01025. https://doi.org/10.1029/2011JG001782

Dupas, R., Curie, F., Gascuel-Odoux, C., Moatar, F., Delmas, M., Parnaudeau, V., Durand, P., 2013. Assessing $\mathrm{N}$ emissions in surface water at the national level: Comparison of country-wide vs. regionalized models. Sci. Total Environ. 443, 152-162. https://doi.org/10.1016/j.scitotenv.2012.10.011

Dupas, R., Delmas, M., Dorioz, J.-M., Garnier, J., Moatar, F., Gascuel-Odoux, C., 2015. Assessing the impact of agricultural pressures on $\mathrm{N}$ and $\mathrm{P}$ loads and eutrophication risk. Ecol. Indic. 48, 396-407. https://doi.org/10.1016/j.ecolind.2014.08.007

Dupas, R., Jomaa, S., Musolff, A., Borchardt, D., Rode, M., 2016. Disentangling the influence of hydroclimatic patterns and agricultural management on river nitrate dynamics from subhourly to decadal time scales. Sci. Total Environ. 571, 791-800. https://doi.org/10.1016/j.scitotenv.2016.07.053

Dupas, R., Musolff, A., Jawitz, J.W., Rao, P.S.C., Jäger, C.G., Fleckenstein, J.H., Rode, M., Borchardt, D., 2017. Carbon and nutrient export regimes from headwater catchments to downstream reaches. Biogeosciences 14, 4391-4407. https://doi.org/10.5194/bg-14-4391-2017 
Ellis, E.C., Klein Goldewijk, K., Siebert, S., Lightman, D., Ramankutty, N., 2010. Anthropogenic transformation of the biomes, 1700 to 2000: Anthropogenic transformation of the biomes. Glob. Ecol. Biogeogr. 586-606. https://doi.org/10.1111/j.1466-8238.2010.00540.x

Exner-Kittridge, M., Strauss, P., Blöschl, G., Eder, A., Saracevic, E., Zessner, M., 2016. The seasonal dynamics of the stream sources and input flow paths of water and nitrogen of an Austrian headwater agricultural catchment. Sci. Total Environ. 542, Part A, 935-945. https://doi.org/10.1016/j.scitotenv.2015.10.151

Foley, J.A., Ramankutty, N., Brauman, K.A., Cassidy, E.S., Gerber, J.S., Johnston, M., Mueller, N.D., O'Connell, C., Ray, D.K., West, P.C., Balzer, C., Bennett, E.M., Carpenter, S.R., Hill, J., Monfreda, C., Polasky, S., Rockström, J., Sheehan, J., Siebert, S., Tilman, D., Zaks, D.P.M., 2011. Solutions for a cultivated planet. Nature 478, 337-342. https://doi.org/10.1038/nature10452

Fovet, O., Ruiz, L., Faucheux, M., Molénat, J., Sekhar, M., Vertès, F., Aquilina, L., Gascuel-Odoux, C., Durand, P., 2015. Using long time series of agricultural-derived nitrates for estimating catchment transit times. J. Hydrol. 522, 603-617. https://doi.org/10.1016/j.jhydrol.2015.01.030

Gardiner, M.M., Allee, L.L., Brown, P.M., Losey, J.E., Roy, H.E., Smyth, R.R., 2012. Lessons from lady beetles: accuracy of monitoring data from US and UK citizen-science programs. Front. Ecol. Environ. 10, 471-476. https://doi.org/10.1890/110185

Gascuel-Odoux, C., Aurousseau, P., Durand, P., Ruiz, L., Molenat, J., 2010. The role of climate on inter-annual variation in stream nitrate fluxes and concentrations. Sci. Total Environ., Special Section: Integrating Water and Agricultural Management Under Climate Change 408, 56575666. https://doi.org/10.1016/j.scitotenv.2009.05.003

Gu, S., Gruau, G., Dupas, R., Rumpel, C., Crème, A., Fovet, O., Gascuel-Odoux, C., Jeanneau, L., Humbert, G., Petitjean, P., 2017. Release of dissolved phosphorus from riparian wetlands: Evidence for complex interactions among hydroclimate variability, topography and soil properties. Sci. Total Environ. 598, 421-431. https://doi.org/10.1016/j.scitotenv.2017.04.028

Hering, D., Borja, A., Carstensen, J., Carvalho, L., Elliott, M., Feld, C.K., Heiskanen, A.-S., Johnson, R.K., Moe, J., Pont, D., Solheim, A.L., de Bund, W. van, 2010. The European Water Framework Directive at the age of 10: A critical review of the achievements with recommendations for the future. Sci. Total Environ. 408, 4007-4019. https://doi.org/10.1016/j.scitotenv.2010.05.031

House, W.A., Leach, D.V., Armitage, P.D., 2001. Study of dissolved silicon, and nitrate dynamics in a fresh water stream. Water Res. 35, 2749-2757. https://doi.org/10.1016/S00431354(00)00548-0

Howarth, R.W., 2008. Coastal nitrogen pollution: A review of sources and trends globally and regionally. Harmful Algae, $\mathrm{HABs}$ and Eutrophication 8, 14-20. https://doi.org/10.1016/j.hal.2008.08.015

Howden, N.J.K., Burt, T.P., Worrall, F., Mathias, S., Whelan, M.J., 2011. Nitrate pollution in intensively farmed regions: What are the prospects for sustaining high-quality groundwater? Water Resour. Res. 47, W00L02. https://doi.org/10.1029/2011WR010843

Jarvie, H.P., Sharpley, A.N., Withers, P.J.A., Scott, J.T., Haggard, B.E., Neal, C., 2013. Phosphorus Mitigation to Control River Eutrophication: Murky Waters, Inconvenient Truths, and "Postnormal" Science. J. Environ. Qual. 42, 295-304. https://doi.org/10.2134/jeq2012.0085

Jasechko, S., Perrone, D., Befus, K.M., Bayani Cardenas, M., Ferguson, G., Gleeson, T., Luijendijk, E., McDonnell, J.J., Taylor, R.G., Wada, Y., Kirchner, J.W., 2017. Global aquifers dominated by fossil groundwaters but wells vulnerable to modern contamination. Nat. Geosci. 10, 425429. https://doi.org/10.1038/ngeo2943

Jenny, J.-P., Normandeau, A., Francus, P., Taranu, Z.E., Gregory-Eaves, I., Lapointe, F., Jautzy, J., Ojala, A.E.K., Dorioz, J.-M., Schimmelmann, A., Zolitschka, B., 2016. Urban point sources of nutrients were the leading cause for the historical spread of hypoxia across European lakes. Proc. Natl. Acad. Sci. 201605480. https://doi.org/10.1073/pnas.1605480113 
Kolbe, T., Marçais, J., Thomas, Z., Abbott, B.W., de Dreuzy, J.-R., Rousseau-Gueutin, P., Aquilina, L., Labasque, T., Pinay, G., 2016. Coupling 3D groundwater modeling with CFC-based age dating to classify local groundwater circulation in an unconfined crystalline aquifer. J. Hydrol. 543, Part A, 31-46. https://doi.org/10.1016/j.jhydrol.2016.05.020

Komsta, L., 2005. Median-Based Linear Models. R Package Version.

Kyba, C.C.M., Wagner, J.M., Kuechly, H.U., Walker, C.E., Elvidge, C.D., Falchi, F., Ruhtz, T., Fischer, J., Hölker, F., 2013. Citizen Science Provides Valuable Data for Monitoring Global Night Sky Luminance. Sci. Rep. 3, 1835. https://doi.org/10.1038/srep01835

Legendre, P., Borcard, D., Roberts, D.W., 2012. Variation partitioning involving orthogonal spatial eigenfunction submodels. Ecology 93, 1234-1240. https://doi.org/10.1890/11-2028.1

Legendre, P., Gauthier, O., 2014. Statistical methods for temporal and space-time analysis of community composition data. Proc. R. Soc. B Biol. Sci. 281, 20132728-20132728. https://doi.org/10.1098/rspb.2013.2728

Linton, J., 2014. Modern water and its discontents: a history of hydrosocial renewal. Wiley Interdiscip. Rev. Water 1, 111-120. https://doi.org/10.1002/wat2.1009

Liu, J., Yang, W., 2012. Water sustainability for China and beyond. Science 337, 649-650.

Martin, C., Aquilina, L., Gascuel-Odoux, C., Molénat, J., Faucheux, M., Ruiz, L., 2004. Seasonal and interannual variations of nitrate and chloride in stream waters related to spatial and temporal patterns of groundwater concentrations in agricultural catchments. Hydrol. Process. 18, 1237-1254. https://doi.org/10.1002/hyp.1395

McDonald, R.I., Weber, K.F., Padowski, J., Boucher, T., Shemie, D., 2016. Estimating watershed degradation over the last century and its impact on water-treatment costs for the world's large cities. Proc. Natl. Acad. Sci. 113, 9117-9122. https://doi.org/10.1073/pnas.1605354113

MEDD \& Agences de l'eau, 2003. Système d'évaluation de la qualité de l'eau des cours d'eau.

Mellander, P.-E., Melland, A.R., Murphy, P.N.C., Wall, D.P., Shortle, G., Jordan, P., 2014. Coupling of surface water and groundwater nitrate- $\mathrm{N}$ dynamics in two permeable agricultural catchments. J. Agric. Sci. 152, S107-S124.

Meter, K.J.V., Basu, N.B., 2015. Catchment Legacies and Time Lags: A Parsimonious Watershed Model to Predict the Effects of Legacy Storage on Nitrogen Export. PLOS ONE 10, e0125971. https://doi.org/10.1371/journal.pone.0125971

Meter, K.J.V., Basu, N.B., Veenstra, J.J., Burras, C.L., 2016. The nitrogen legacy: emerging evidence of nitrogen accumulation in anthropogenic landscapes. Environ. Res. Lett. 11, 035014. https://doi.org/10.1088/1748-9326/11/3/035014

Meybeck, M., Moatar, F., 2012. Daily variability of river concentrations and fluxes: indicators based on the segmentation of the rating curve. Hydrol. Process. 26, 1188-1207. https://doi.org/10.1002/hyp.8211

Minaudo, C., Meybeck, M., Moatar, F., Gassama, N., Curie, F., 2015. Eutrophication mitigation in rivers: 30 years of trends in spatial and seasonal patterns of biogeochemistry of the Loire River (1980-2012). Biogeosciences 12, 2549-2563. https://doi.org/10.5194/bg-12-2549-2015

Moatar, F., Abbott, B.W., Minaudo, C., Curie, F., Pinay, G., 2017. Elemental properties, hydrology, and biology interact to shape concentration-discharge curves for carbon, nutrients, sediment, and major ions. Water Resour. Res. 53, 1270-1287. https://doi.org/10.1002/2016WR019635

Moatar, F., Meybeck, M., Raymond, S., Birgand, F., Curie, F., 2013. River flux uncertainties predicted by hydrological variability and riverine material behaviour. Hydrol. Process. 27, 3535-3546. https://doi.org/10.1002/hyp.9464

Musolff, A., Schmidt, C., Rode, M., Lischeid, G., Weise, S.M., Fleckenstein, J.H., 2016. Groundwater head controls nitrate export from an agricultural lowland catchment. Adv. Water Resour. 96, 95-107. https://doi.org/10.1016/j.advwatres.2016.07.003

Musolff, A., Schmidt, C., Selle, B., Fleckenstein, J.H., 2015. Catchment controls on solute export. Adv. Water Resour. 86, 133-146. https://doi.org/10.1016/j.advwatres.2015.09.026 
Neal, C., Neal, M., Wickham, H., Harrow, M., 2000. The water quality of a tributary of the Thames, the Pang, southern England. Sci. Total Environ. 251-252, 459-475. https://doi.org/10.1016/S0048-9697(00)00399-5

Ohtani, K., 2004. Sampling Properties of R-squared When an Inequality. Kobe Univ. Econ. Rev. 50, 112.

Oksanen, J., Kindt, R., Legendre, P., O'Hara, B., Stevens, M.H.H., Oksanen, M.J., Suggests, M., 2007. The vegan package. Community Ecol. Package 10, 631-637.

Oulehle, F., Cosby, B.J., Austnes, K., Evans, C.D., Hruška, J., Kopáček, J., Moldan, F., Wright, R.F., 2015. Modelling inorganic nitrogen in runoff: Seasonal dynamics at four European catchments as simulated by the MAGIC model. Sci. Total Environ. 536, 1019-1028. https://doi.org/10.1016/j.scitotenv.2015.05.047

Perrot, T., Rossi, N., Ménesguen, A., Dumas, F., 2014. Modelling green macroalgal blooms on the coasts of Brittany, France to enhance water quality management. J. Mar. Syst. 132, 38-53. https://doi.org/10.1016/j.jmarsys.2013.12.010

Pinay, G., Peiffer, S., De Dreuzy, J.-R., Krause, S., Hannah, D.M., Fleckenstein, J.H., Sebilo, M., Bishop, K., Hubert-Moy, L., 2015. Upscaling Nitrogen Removal Capacity from Local Hotspots to Low Stream Orders' Drainage Basins. Ecosystems 18, 1101-1120. https://doi.org/10.1007/s10021-015-9878-5

Piot-Lepetit, I., Moing, M.L., 2007. Productivity and environmental regulation: the effect of the nitrates directive in the French pig sector. Environ. Resour. Econ. 38, 433-446. https://doi.org/10.1007/s10640-007-9086-7

Poisvert, C., Curie, F., Moatar, F., 2017. Annual agricultural N surplus in France over a 70-year period. Nutr. Cycl. Agroecosystems 107, 63-78. https://doi.org/10.1007/s10705-016-9814-x

R Core Team, 2016. R: A language and environment for statistical computing. R Foundation for Statistical Computing,. Vienna, Austria.

Raymond, S., Moatar, F., Meybeck, M., Bustillo, V., 2013. Choosing methods for estimating dissolved and particulate riverine fluxes from monthly sampling. Hydrol. Sci. J. 58, 1326-1339. https://doi.org/10.1080/02626667.2013.814915

Reed, D.C., Harrison, J.A., 2016. Linking nutrient loading and oxygen in the coastal ocean: A new global scale model. Glob. Biogeochem. Cycles 30, 2015 GB005303. https://doi.org/10.1002/2015GB005303

Regional Algal Bloom Plans, 2015. Plan gouvernemental de lutte contre les algues vertes 2010-2015.

Regional Counsel, 2013. Région_Bretagne - mise en oeuvre de la strategie regionale de lutte contre les marees vertes.

Ruhala, S.S., Zarnetske, J.P., 2017. Using in-situ optical sensors to study dissolved organic carbon dynamics of streams and watersheds: A review. Sci. Total Environ. 575, 713-723. https://doi.org/10.1016/j.scitotenv.2016.09.113

Savage, N., 2012. Gaining Wisdom from Crowds. Commun ACM 55, 13-15. https://doi.org/10.1145/2093548.2093553

Schmidt, J.J., 2014. Historicizing the hydrosocial cycle. Water Altern. 7.

Schoumans, O.F., Silgram, M., Groenendijk, P., Bouraoui, F., Andersen, H.E., Kronvang, B., Behrendt, H., Arheimer, B., Johnsson, H., Panagopoulos, Y., Mimikou, M., Porto, A.L., Reisser, H., Gall, G.L., Barr, A., Anthony, S.G., 2009. Description of nine nutrient loss models: capabilities and suitability based on their characteristics. J. Environ. Monit. 11, 506-514. https://doi.org/10.1039/B823239C

Sebilo, M., Mayer, B., Nicolardot, B., Pinay, G., Mariotti, A., 2013. Long-term fate of nitrate fertilizer in agricultural soils. Proc. Natl. Acad. Sci. 110, 18185-18189. https://doi.org/10.1073/pnas.1305372110

Seitzinger, S., Harrison, J.A., Böhlke, J.K., Bouwman, A.F., Lowrance, R., Peterson, B., Tobias, C., Drecht, G.V., 2006. Denitrification across landscapes and waterscapes: a synthesis. Ecol. Appl. 16, 2064-2090. https://doi.org/10.1890/1051-0761(2006)016[2064:DALAWA]2.0.CO;2 
Seitzinger, S.P., Mayorga, E., Bouwman, A.F., Kroeze, C., Beusen, A.H.W., Billen, G., Van Drecht, G., Dumont, E., Fekete, B.M., Garnier, J., Harrison, J.A., 2010. Global river nutrient export: A scenario analysis of past and future trends. Glob. Biogeochem. Cycles 24, GBOA08. https://doi.org/10.1029/2009GB003587

Silvertown, J., 2009. A new dawn for citizen science. Trends Ecol. Evol. 24, 467-471. https://doi.org/10.1016/j.tree.2009.03.017

Stålnacke, P., Grimvall, A., Libiseller, C., Laznik, M., Kokorite, I., 2003. Trends in nutrient concentrations in Latvian rivers and the response to the dramatic change in agriculture. J. Hydrol. 283, 184-205. https://doi.org/10.1016/S0022-1694(03)00266-X

Sutton, M.A., UNEP (Eds.), 2013. Our nutrient world: the challenge to produce more food and energy with less pollution; [global overview on nutrient management]. Centre for Ecology \& Hydrology, Edinburgh.

Thomas, Z., Abbott, B.W., Troccaz, O., Baudry, J., Pinay, G., 2016a. Proximate and ultimate controls on carbon and nutrient dynamics of small agricultural catchments. Biogeosciences 13, 18631875. https://doi.org/10.5194/bg-13-1863-2016

Thomas, Z., Rousseau-Gueutin, P., Kolbe, T., Abbott, B.W., Marçais, J., Peiffer, S., Frei, S., Bishop, K., Pichelin, P., Pinay, G., de Dreuzy, J.-R., 2016b. Constitution of a catchment virtual observatory for sharing flow and transport models outputs. J. Hydrol., RESIDENCE TIMES IN SUBSURFACE HYDROLOGICAL SYSTEMS: Signature of hydrological processes and impact on environmental applications 543, 59-66. https://doi.org/10.1016/j.jhydrol.2016.04.067

Tunaley, C., Tetzlaff, D., Lessels, J., Soulsby, C., 2016. Linking high-frequency DOC dynamics to the age of connected water sources. Water Resour. Res. 52, 5232-5247. https://doi.org/10.1002/2015WR018419

Vilmin, L., Flipo, N., Escoffier, N., Groleau, A., 2016. Estimation of the water quality of a large urbanized river as defined by the European WFD: what is the optimal sampling frequency? Environ. Sci. Pollut. Res. 1-17. https://doi.org/10.1007/s11356-016-7109-z

Wickham, H., 2009. ggplot2: Elegant Graphics for Data Analysis. Springer New York, New York, NY. https://doi.org/10.1007/978-0-387-98141-3

Wilcock, R.J., Monaghan, R.M., Quinn, J.M., Srinivasan, M.S., Houlbrooke, D.J., Duncan, M.J., WrightStow, A.E., Scarsbrook, M.R., 2013. Trends in water quality of five dairy farming streams in response to adoption of best practice and benefits of long-term monitoring at the catchment scale. Mar. Freshw. Res. 64, 401-412. https://doi.org/10.1071/MF12155

Withers, P.J.A., Haygarth, P.M., 2007. Agriculture, phosphorus and eutrophication: a European perspective. Soil Use Manag. 23, 1-4. https://doi.org/10.1111/j.1475-2743.2007.00116.x

Worrall, F., Howden, N.J.K., Burt, T.P., 2015. Time series analysis of the world's longest fluvial nitrate record: evidence for changing states of catchment saturation. Hydrol. Process. 29, 434-444. https://doi.org/10.1002/hyp.10164

Zhang, Q., Brady, D.C., Boynton, W.R., Ball, W.P., 2015. Long-Term Trends of Nutrients and Sediment from the Nontidal Chesapeake Watershed: An Assessment of Progress by River and Season. JAWRA J. Am. Water Resour. Assoc. 51, 1534-1555. https://doi.org/10.1111/17521688.12327 
Table 1. Catchment characteristics for the 13 studied rivers in western France

\begin{tabular}{|c|c|c|c|c|c|c|c|c|c|c|c|c|c|c|c|c|c|c|c|}
\hline \multirow[b]{2}{*}{ River (ID) } & \multicolumn{5}{|c|}{ General } & \multicolumn{3}{|c|}{ Hydrologic** } & \multicolumn{6}{|c|}{ Land cover } & \multicolumn{3}{|c|}{ Geologic substrate } & \multicolumn{2}{|c|}{ Nutrient loading } \\
\hline & $\begin{array}{l}\text { Area } \\
\mathrm{km}^{2}\end{array}$ & $\begin{array}{c}\text { Population } \\
\text { hab km² }\end{array}$ & $\begin{array}{c}\begin{array}{c}\text { Altitude } \\
\text { (mean) } \\
\mathrm{m}\end{array} \\
\end{array}$ & $\begin{array}{c}\text { Relief } \\
\mathrm{m} \\
\end{array}$ & $\begin{array}{c}\text { Rainfall } \\
\mathrm{mm}\end{array}$ & \begin{tabular}{|c|}
$\mathbf{Q}$ \\
specific \\
$1 \mathrm{l} \mathrm{s}^{-1} \mathrm{~km}^{-2}$ \\
\end{tabular} & $\begin{array}{c}\text { Q specific } \\
\text { min } \\
\mathrm{l} \mathrm{s}^{-1} \mathrm{~km}^{-2} \\
\end{array}$ & $\begin{array}{c}\text { W2 } \\
\%\end{array}$ & \begin{tabular}{|c} 
Pasture \\
$\%$ \\
\end{tabular} & $\begin{array}{c}\text { Crops } \\
\% \\
\end{array}$ & $\begin{array}{c}\text { Hedgerow } \\
\% \\
\end{array}$ & $\begin{array}{c}\text { Forest } \\
\% \\
\end{array}$ & $\begin{array}{c}\text { Wetland } \\
\% \\
\end{array}$ & $\begin{array}{c}\text { Urban } \\
\% \\
\end{array}$ & $\begin{array}{c}\begin{array}{c}\text { Granite } \\
\text { gneiss } \\
\%\end{array} \\
\end{array}$ & $\begin{array}{c}\text { Schist } \\
\% \\
\end{array}$ & $\begin{array}{c}\text { Other } \\
\% \\
\end{array}$ & $\begin{array}{c}\text { N Surplus } \\
\text { (2007) } \\
\text { kg N ha }^{-1} \\
\end{array}$ & $\begin{array}{c}\text { P Surplus } \\
\text { (2010) } \\
\text { kg P ha }^{-1} \\
\end{array}$ \\
\hline St-Laurent (1) & 30 & 223 & 90 & 152 & 1151 & - & - & - & 9 & 28 & 55 & 2 & 3 & 2 & 100 & 0 & 0 & 19 & 19 \\
\hline $\operatorname{Ris}(2)^{*}$ & 36 & 92 & 82 & 224 & 1242 & - & - & - & 3 & 32 & 60 & 1 & 0 & 3 & 90 & 10 & 0 & - & - \\
\hline Lapic (3)* & 26 & 64 & 91 & 276 & 1251 & - & - & - & 5 & 39 & 50 & 0 & 1 & 5 & 18 & 82 & 0 & 46 & 23 \\
\hline Kerharo $(4)^{*}$ & 45 & 51 & 85 & 378 & 1202 & - & - & - & 2 & 32 & 60 & 0 & 0 & 6 & 0 & 84 & 16 & 34 & 24 \\
\hline Aulne (5) & 1489 & 36 & 164 & 376 & 1237 & 18.2 & 2.5 & 10.3 & 29 & 28 & 32 & 2 & 0 & 8 & 10 & 81 & 3 & 40 & 21 \\
\hline Douffine (6) & 159 & 27 & 156 & 363 & 1395 & 23.5 & 4.1 & 11.4 & 18 & 24 & 39 & 7 & 0 & 12 & 0 & 89 & 11 & 51 & 31 \\
\hline Elorn (7) & 279 & 100 & 126 & 380 & 1277 & 21.8 & 7 & 9.6 & 10 & 44 & 36 & 1 & 0 & 9 & 35 & 55 & 3 & 60 & 31 \\
\hline Quillimadec (8) & 29 & 141 & 70 & 89 & 1184 & - & - & - & 1 & 33 & 63 & 0 & 0 & 3 & 88 & 0 & 12 & 65 & 21 \\
\hline Fleche (9) & 65 & 64 & 75 & 115 & 1158 & - & - & - & 0 & 53 & 42 & 0 & 0 & 5 & 88 & 0 & 8 & 75 & 27 \\
\hline Guillec (10)* & 73 & 77 & 73 & 117 & 1055 & 16.1 & 6.2 & 7.2 & 0 & 82 & 16 & 0 & 0 & 2 & 15 & 0 & 85 & 65 & 27 \\
\hline Penze (11)* & 142 & 50 & 149 & 373 & 1167 & 20.3 & 4.9 & 7.7 & 26 & 40 & 29 & 0 & 0 & 5 & 57 & 35 & 0 & 54 & 23 \\
\hline Dossen (12) & 191 & 83 & 153 & 364 & 1139 & 16.7 & 4.7 & 7.6 & 28 & 31 & 27 & 4 & 0 & 10 & 45 & 49 & 0 & 37 & 29 \\
\hline Dourduff (13) & 69 & 133 & 94 & 172 & 990 & 12.2 & 2.8 & 8.4 & 6 & 50 & 40 & 0 & 1 & 4 & 0 & 62 & 38 & 39 & 32 \\
\hline
\end{tabular}

*Monitoring of these rivers stopped at the end of 2015 due to limited budget.

**Interannual mean and interannual monthly minimum of specific discharge were calculated from the nearest hydrologic station (details on hydrologic monitoring in Table S1). Altitudes were derived from a $25 \mathrm{~m}$ digital elevation model and lithology was extracted from maps created by the French National Institute for Agricultural Research (INRA). 
Table 2. Medians, flow-weighted concentrations, and nutrient yields for $\mathrm{NO}_{3}{ }^{-}, \mathrm{PO}_{4}{ }^{3-}$ and dissolved silica (DSi; 1998-2016)

\begin{tabular}{|c|c|c|c|c|c|c|c|c|c|}
\hline \multirow[b]{2}{*}{ River (ID) } & \multicolumn{3}{|c|}{$\mathrm{NO}_{3}{ }^{-}$} & \multicolumn{3}{|c|}{$\mathbf{P O}_{4}{ }^{3-}$} & \multicolumn{3}{|c|}{ DSi } \\
\hline & $\begin{array}{c}\text { C50 } \\
\text { mg L }^{-1}\end{array}$ & $\begin{array}{c}\mathrm{C}^{*} \\
\mathrm{mg} \mathrm{L}^{-1}\end{array}$ & $\begin{array}{c}\text { Load } \\
\text { kg N ha }^{-1} y^{-1}\end{array}$ & $\begin{array}{c}\text { C50 } \\
\text { mg L }^{-1}\end{array}$ & $\begin{array}{c}\mathrm{C}^{*} \\
\mathrm{mg} \mathrm{L}^{-1}\end{array}$ & 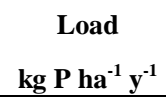 & $\begin{array}{c}\text { C50 } \\
\text { mg L }^{-1}\end{array}$ & $\begin{array}{c}\mathrm{C}^{*} \\
\mathrm{mg} \mathrm{L}^{-1}\end{array}$ & $\begin{array}{c}\text { Load } \\
\text { kg Si ha }^{-1} \mathrm{y}^{-1}\end{array}$ \\
\hline St-Laurent (1) & 41.2 & & & 0.033 & & & 12.2 & & \\
\hline Ris (2) & 35.0 & & & 0.097 & & & 14.9 & & \\
\hline Lapic (3) & 41.2 & & & 0.209 & & & 11.3 & & \\
\hline Kerharo (4) & 35.0 & & & 0.086 & & & 9.18 & & \\
\hline Aulne (5) & 22.1 & 26.6 & $37( \pm 12 \%)$ & 0.054 & 0.061 & $0.12( \pm 12 \%)$ & 7.6 & 7.8 & $47( \pm 9 \%)$ \\
\hline Douffine (6) & 19.0 & 20.4 & 36 ( $\pm 13 \%)$ & 0.212 & 0.139 & $0.34( \pm 3 \%)$ & 5.7 & 5.4 & $42( \pm 10 \%)$ \\
\hline Elorn (7) & 34.1 & 32.3 & $48( \pm 5 \%)$ & 0.212 & 0.139 & $0.28( \pm 7 \%)$ & 9.2 & 8.5 & 57 ( $\pm 5 \%)$ \\
\hline Quillimadec (8) & 50.9 & & & 0.418 & & & 16.1 & & \\
\hline Fleche (9) & 61.1 & & & 0.272 & & & 14.4 & & \\
\hline Guillec (10) & 77.5 & 69.5 & $81( \pm 3 \%)$ & 0.394 & 0.318 & $0.54( \pm 5 \%)$ & 14.0 & 13.2 & $68( \pm 4 \%)$ \\
\hline Penze (11) & 45.2 & 45.2 & $68( \pm 10 \%)$ & 0.397 & 0.230 & $0.50( \pm 4 \%)$ & 11.8 & 11.1 & $73( \pm 8 \%)$ \\
\hline Dossen (12) & 27.0 & 26.1 & $30.4( \pm 7 \%)$ & 0.285 & 0.239 & $0.39( \pm 2 \%)$ & 12.4 & 11.6 & 59 ( $\pm 5 \%)$ \\
\hline Dourduff (13) & 35.9 & 33.6 & $30( \pm 7 \%)$ & 0.224 & 0.154 & $0.20( \pm 12 \%)$ & 13.0 & 12.5 & $47( \pm 5 \%)$ \\
\hline
\end{tabular}


Table 3. Variance explained by the long-term, seasonal, and short-term components of the nutrient fluctuation models

\begin{tabular}{|c|c|c|c|c|c|c|c|c|c|c|c|c|}
\hline \multirow[b]{2}{*}{ River (ID) } & \multicolumn{4}{|c|}{$\mathrm{NO}_{3}^{-}$} & \multicolumn{4}{|c|}{$\mathrm{PO}_{4}^{3-}$} & \multicolumn{4}{|c|}{ DSi } \\
\hline & $\begin{array}{c}\text { Long- } \\
\text { term }\end{array}$ & Seasonal & $\begin{array}{c}\text { Short- } \\
\text { term }\end{array}$ & Total & $\begin{array}{c}\text { Long- } \\
\text { term }\end{array}$ & Seasonal & $\begin{array}{c}\text { Short- } \\
\text { term }\end{array}$ & Total & $\begin{array}{c}\text { Long- } \\
\text { term }\end{array}$ & Seasonal & $\begin{array}{c}\text { Short- } \\
\text { term }\end{array}$ & Total \\
\hline St-Laurent (1) & 0.17 & 0.10 & 0.24 & 0.54 & 0.02 & 0.03 & 0.22 & 0.28 & 0.22 & 0.19 & 0.15 & 0.59 \\
\hline Ris (2) & 0.21 & 0.03 & 0.24 & 0.52 & 0.07 & 0.07 & 0.06 & 0.20 & 0.31 & 0.33 & 0.16 & 0.83 \\
\hline Lapic (3) & 0.29 & 0.31 & 0.11 & 0.78 & 0.13 & $\underline{0.41}$ & 0.24 & 0.78 & 0.22 & 0.10 & 0.21 & 0.61 \\
\hline Aulne (5) & 0.12 & $\underline{0.52}$ & 0.12 & 0.85 & 0.10 & 0.09 & 0.29 & 0.50 & 0.13 & 0.38 & 0.22 & 0.87 \\
\hline Douffine (6) & 0.19 & 0.18 & 0.18 & 0.62 & 0.21 & $\underline{0.42}$ & 0.17 & 0.82 & 0.13 & 0.22 & 0.27 & 0.63 \\
\hline Elorn (7) & 0.17 & 0.15 & 0.22 & 0.58 & 0.16 & 0.27 & 0.18 & 0.60 & 0.09 & 0.18 & 0.35 & 0.69 \\
\hline Quillimadec (8) & 0.18 & 0.15 & 0.19 & 0.57 & 0.14 & 0.14 & 0.21 & 0.52 & 0.06 & 0.32 & 0.24 & 0.60 \\
\hline Fleche (9) & 0.19 & 0.20 & 0.16 & 0.57 & 0.16 & 0.14 & 0.27 & 0.64 & 0.11 & 0.25 & 0.20 & 0.61 \\
\hline Guillec (10) & 0.32 & 0.14 & 0.11 & 0.63 & 0.28 & 0.25 & 0.18 & 0.73 & 0.12 & 0.21 & 0.26 & 0.65 \\
\hline Penze (11) & $\underline{0.46}$ & 0.04 & 0.13 & 0.68 & 0.34 & $\underline{0.43}$ & 0.07 & 0.90 & 0.21 & 0.24 & 0.24 & 0.75 \\
\hline Dossen (12) & 0.29 & 0.07 & 0.21 & 0.61 & 0.20 & 0.32 & 0.13 & 0.71 & 0.15 & 0.17 & 0.38 & 0.71 \\
\hline Dourduff (13) & 0.30 & 0.10 & 0.13 & 0.55 & 0.38 & 0.33 & 0.08 & 0.81 & 0.07 & 0.32 & 0.15 & 0.57 \\
\hline
\end{tabular}

5 Reported values are adjusted- $\mathrm{R}^{2}$ between observed nutrient concentrations and predicted values from one or more sets of 6 explanatory variables in the dbMEM (see Section 2.3.2). All values are significant at $\alpha=0.05$. To facilitate interpretation, 7 we bolded values with $\mathrm{R}^{2}>0.2$ and underlined values with $\mathrm{R}^{2}>0.4$. 


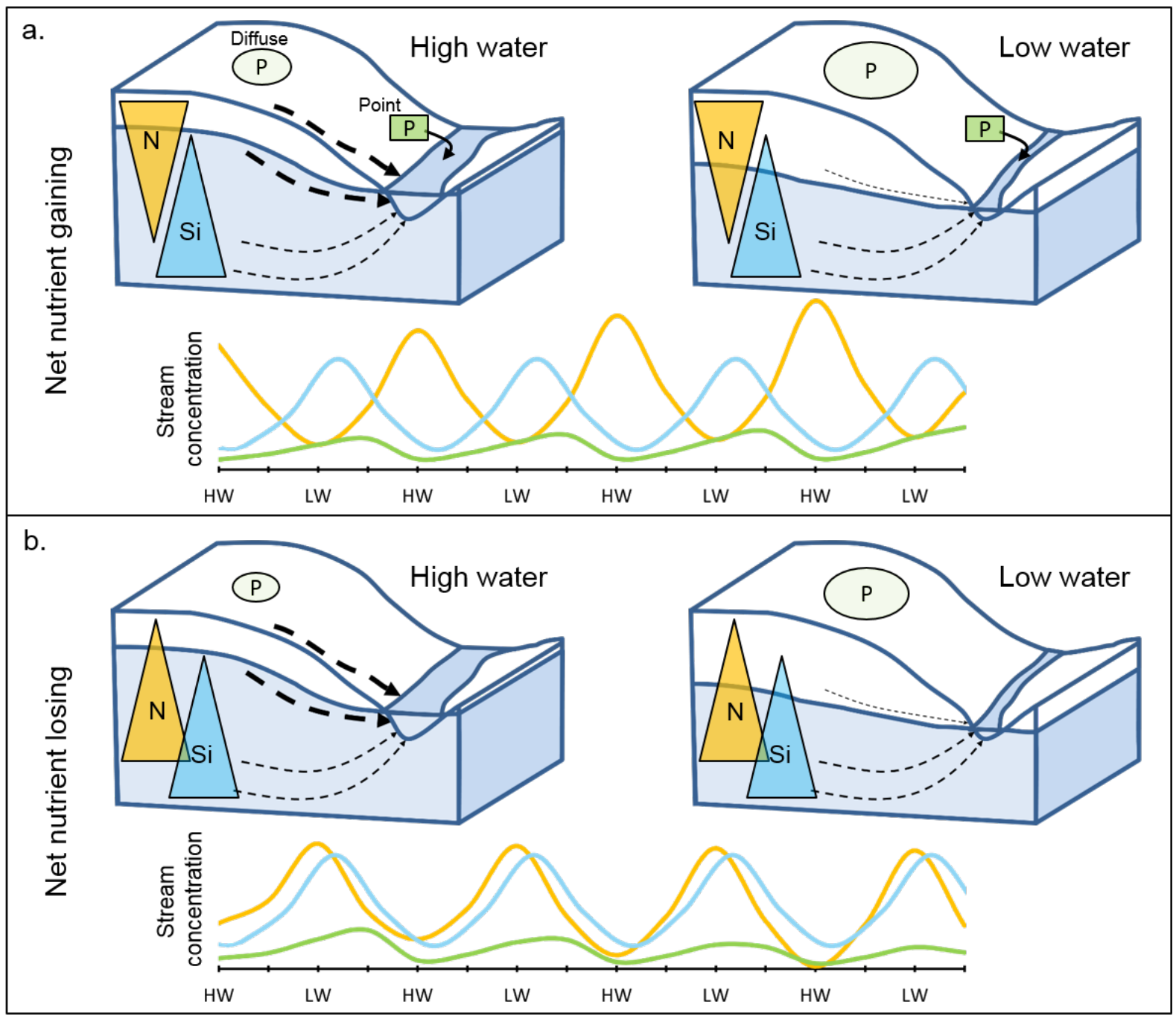

9 Figure 1. Hypothesized seasonal and interannual changes stream concentrations of nitrate $10\left(\mathrm{NO}_{3}{ }^{-}\right)$, dissolved silica (DSi), and phosphate $\left(\mathrm{PO}_{4}{ }^{3-}\right)$ in (a) a catchment experiencing net nutrient gain of $\mathrm{N}$ and $\mathrm{P}$, and (b) a catchment experiencing net nutrient loss of $\mathrm{N}$ and $\mathrm{P}$.

12 Concentrations were simulated with a simple mixing model based on water flow and nutrient availability, assuming conservative transport. Key predictions include: 1. opposite seasonal signals for top-loaded and bottom-loaded nutrients with diffuse sources (e.g. $\mathrm{NO}_{3}{ }^{-}$in a gaining and losing catchment, respectively), 2. greater interannual change for high-water (HW) relative to low-water (LW) concentrations for nutrients with diffuse sources, 3. greater interannual change for LW concentrations for nutrients with seasonally constant point sources (e.g. $\mathrm{PO}_{4}{ }^{3-}$ ), 4. no interannual change in DSi but later arrival of the DSi peak relative to $\mathrm{NO}_{3}{ }^{-}$, due to deeper DSi sources that are not affected by human activity. In a real catchment, the outflow concentration would be further modified by biogeochemical activity, which varies seasonally. However, these predictions are not unrealistic since nutrients are often transported relatively conservatively in highly saturated systems. 


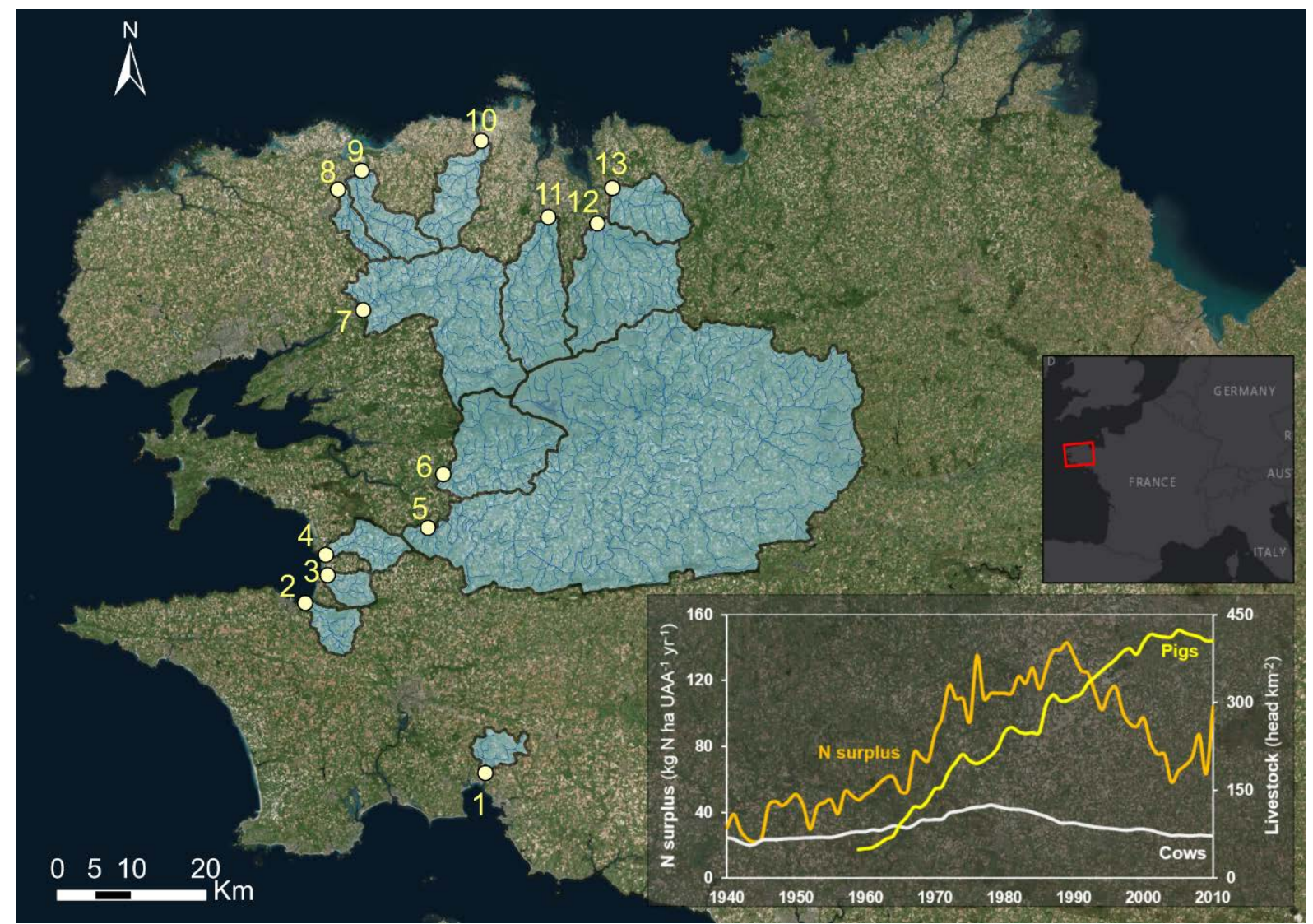

Figure 2. Location of 13 agricultural catchments that were sampled weekly from 1998 to 2016 as a part of a citizen science initiative in Brittany, France. Inset figure shows historical agricultural activity for the Department of Finistère where the catchments are located, including nitrogen surplus, determined by soil surface balance, and density of pigs and cows (Poisvert et al., 2017). Catchment names are listed in Table 1. 


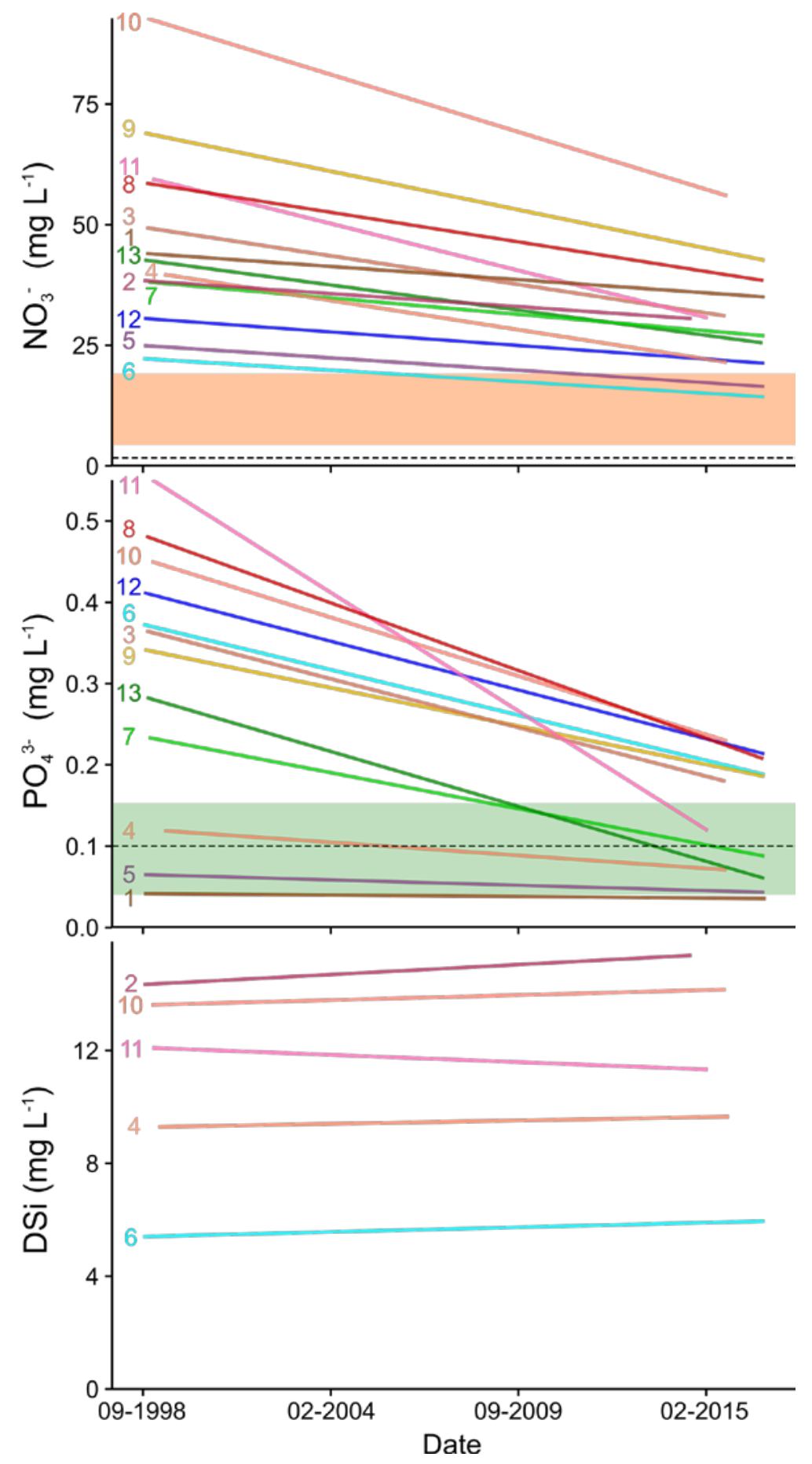

Date

33 Figure 3. Statistically significant long-term trends in nutrient concentrations (Mann-Kendall test $\alpha=0.05$ ). The shaded rectangles for the $\mathrm{NO}_{3}{ }^{-}$and $\mathrm{PO}_{4}{ }^{3-}$ plots represent the estimated concentrations necessary to substantially reduce inland and coastal eutrophication (Dodds et al., 1998; Perrot et al., 2014) and the dotted lines represent the nationally standardized "Blue-

37 Green" targets used by all water agencies in France (MEDD \& Agences de l'eau, 2003).

38 Trends explained 5 to $37 \%$ (median $=17 \%$ ) of total variance of $\mathrm{NO}_{3}{ }^{-}$concentration, 1 to 23

$39 \%$ (median $=10 \%$ ) for $\mathrm{PO}_{4}{ }^{3-}$, and 1 to $3 \%$ (median $=2 \%$ ) for DSi. Detailed summary of 40 linear models is provided in Table S3. 


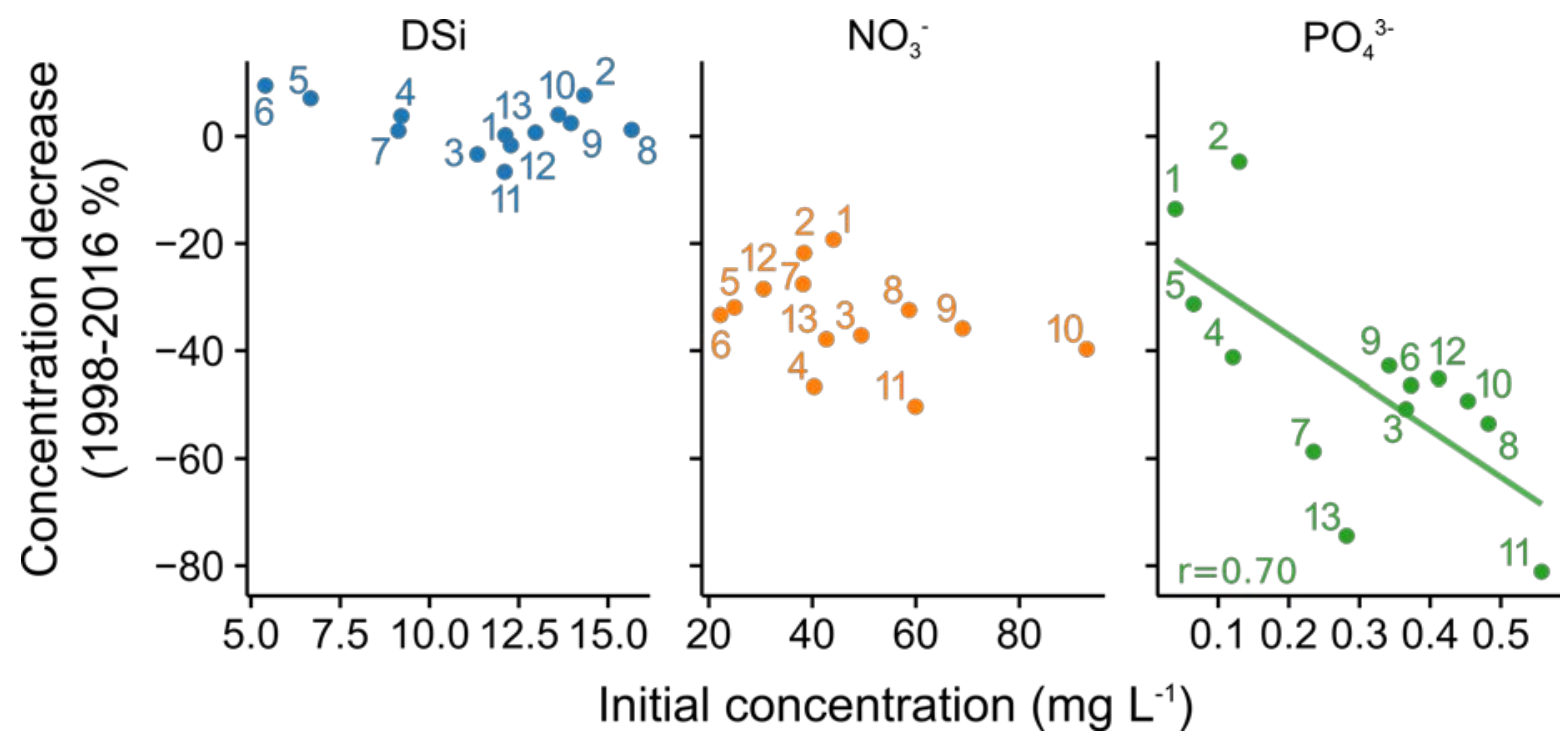

42 Figure 4. Percent change in nutrient concentrations from 1998 to 2016 plotted against initial 43 concentration based on the slope and intercept of the linear models (Fig. 3). 
a.
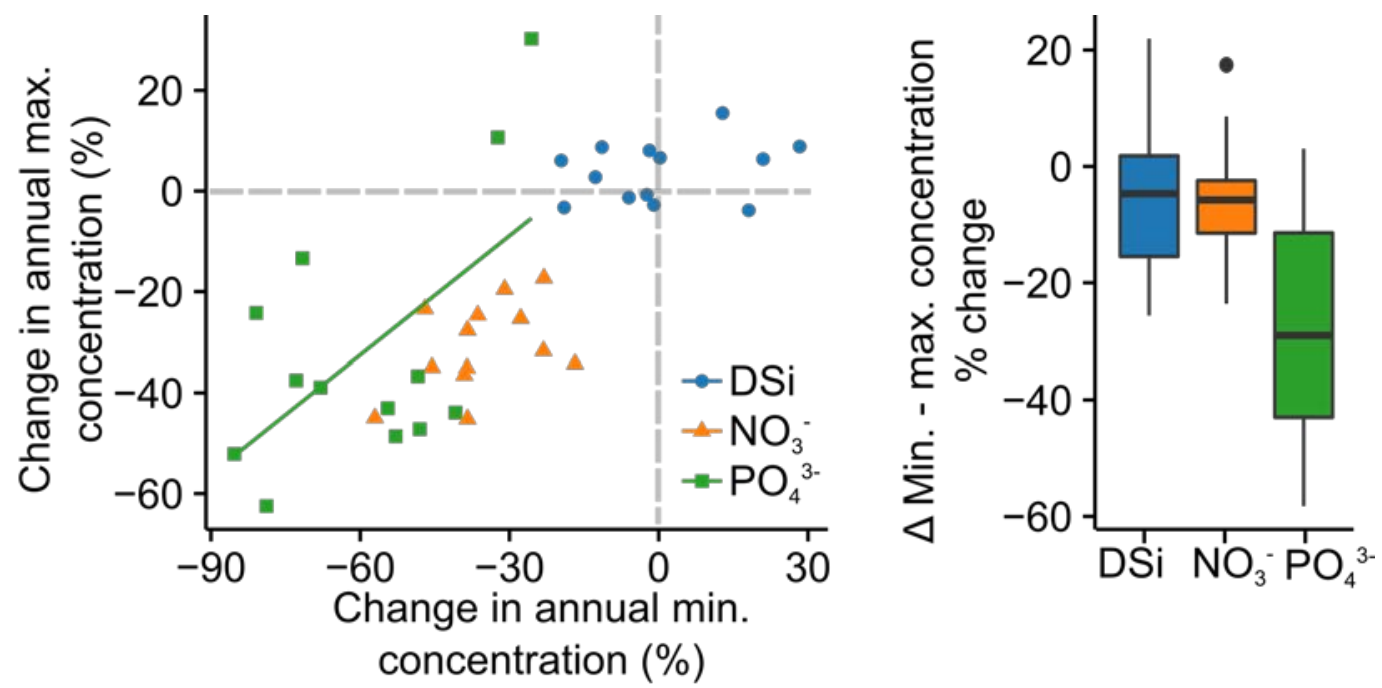

b.
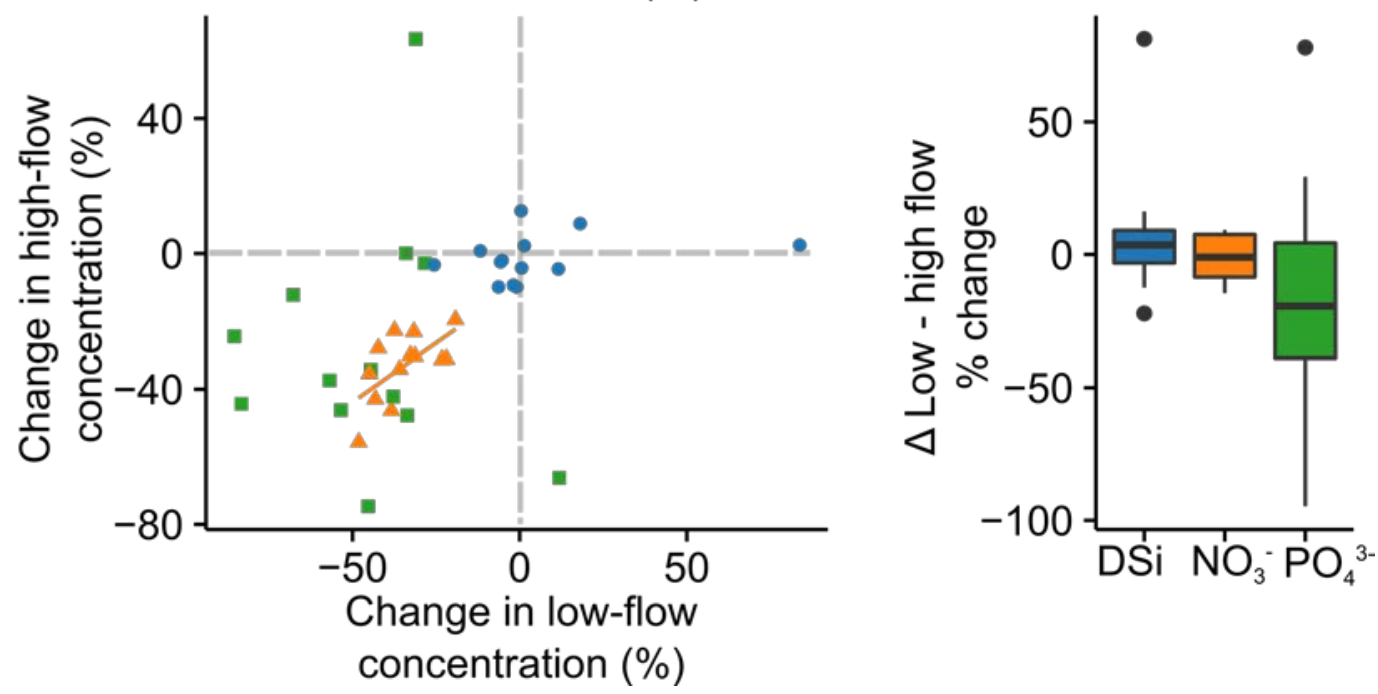

Figure 5. Comparison between trends in (a) annual maximum and minimum concentrations, and (b) annual low-flow and high-flow concentrations. Trends are presented in \% change for each solute from 1998 to 2016. Mean values of the five highest and lowest concentrations annually were used to calculate trends in (a), and mean August concentrations (low-flow period) and mean December concentrations (high-flow) were used to calculate trends in (b). Boxplots represent the difference between trends in min. and max. concentrations and lowflow and high-flow concentrations, with the median, quartiles, minimum and maximum values within the interquartile range, and points beyond 1.5 times the interquartile range. Values above 0 indicate greater change (usually decrease) in max. concentration (a) or highflow concentration (b), while those below the 0 line experienced larger relative change of min. concentrations (a) or during low flows. 

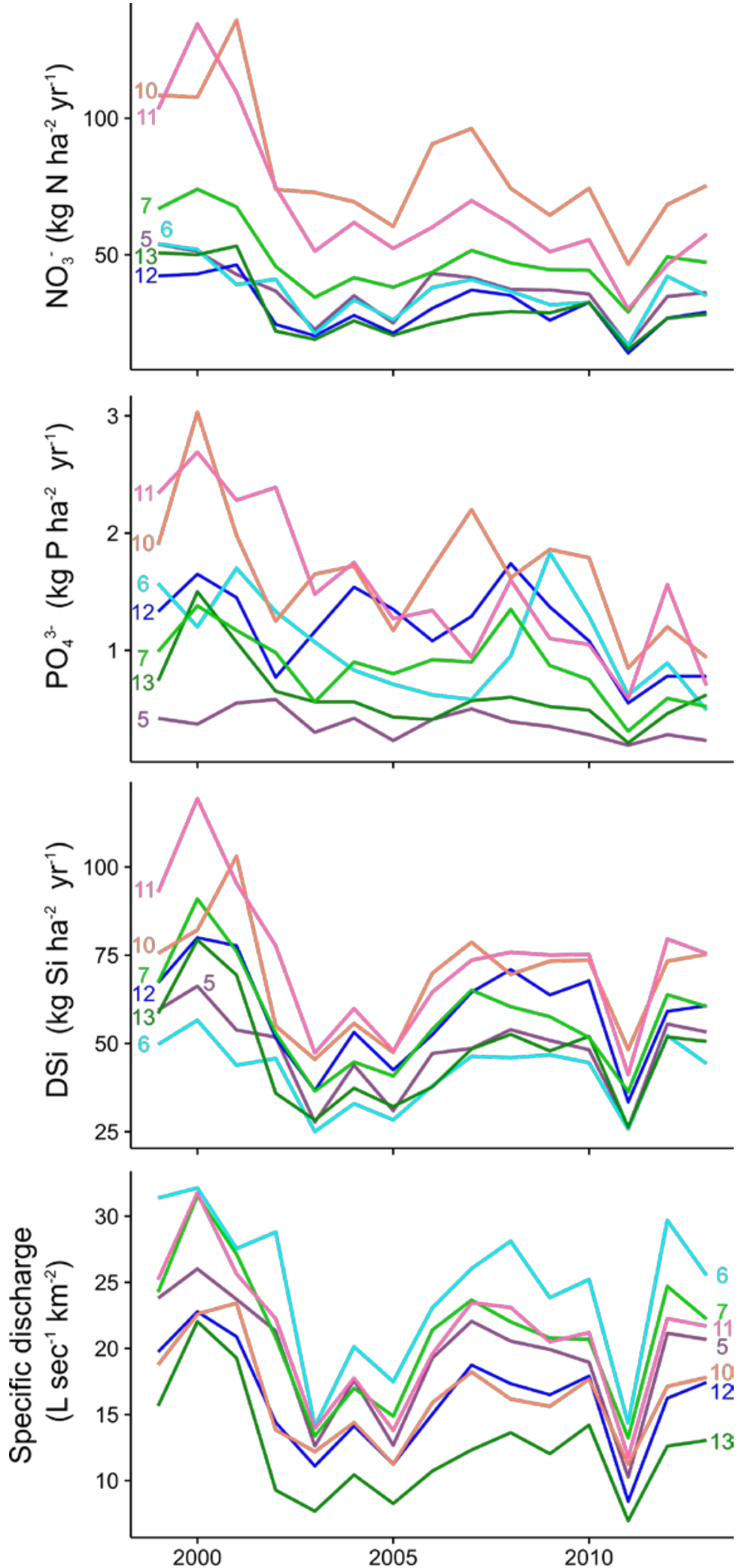

Year

Figure 6. Trends in nutrient and water fluxes for the 7 rivers where long-term discharge data were available. We calculated fluxes with the discharge-weighted concentration method, which was the most robust for these catchments and nutrients (see methods). 

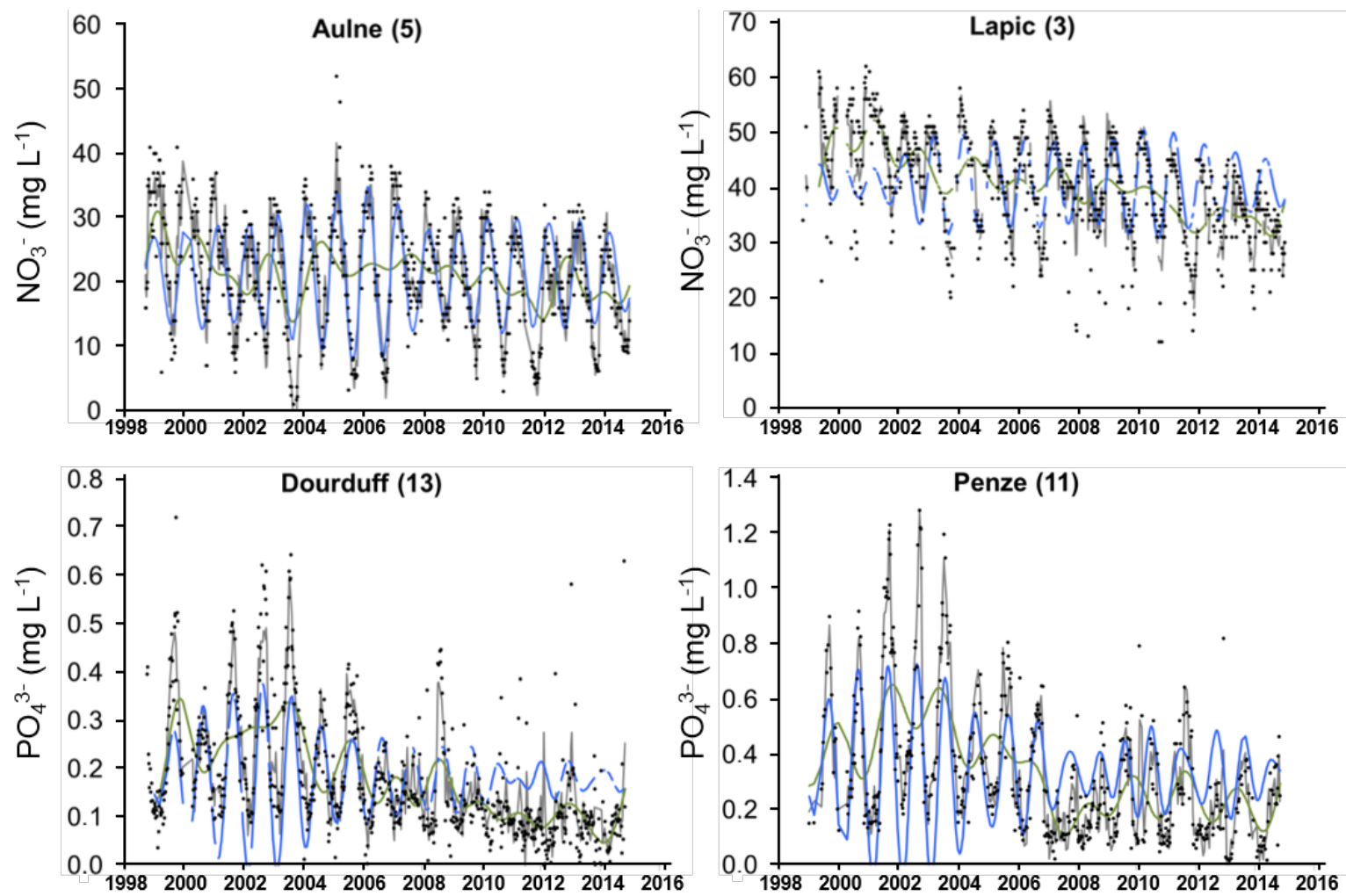

—Model (Seasonal) · Data

94 Figure 7. Example modeled and observed time series, and modeled long-term and seasonal

95 subcomponents from four catchments. See Table 3 for overall model performance and 96 breakdown of timescales. 
a.

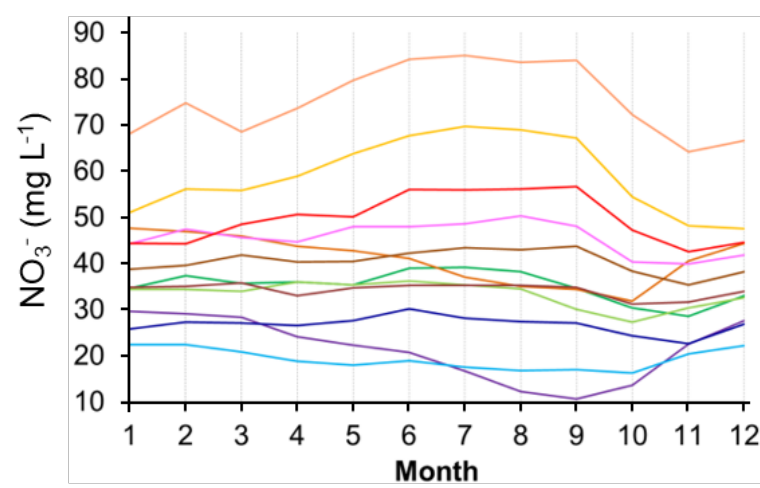

C.

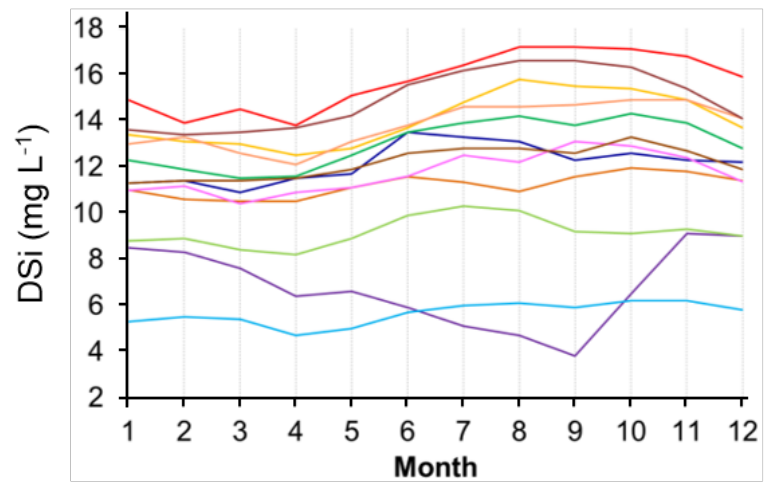

b.

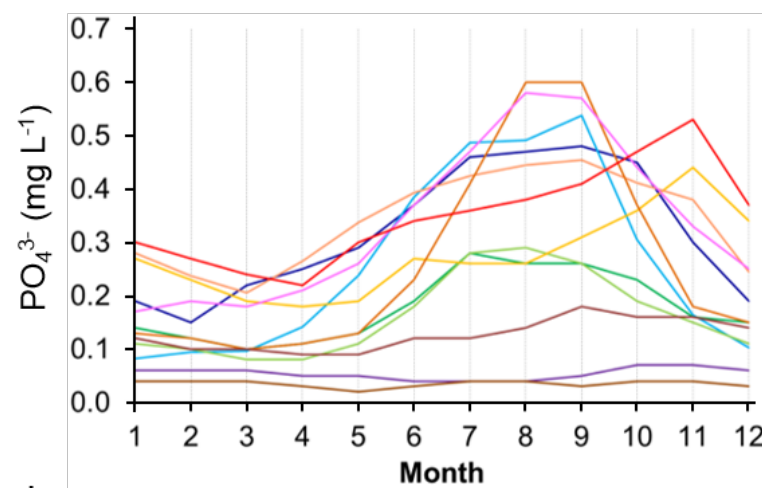

d.

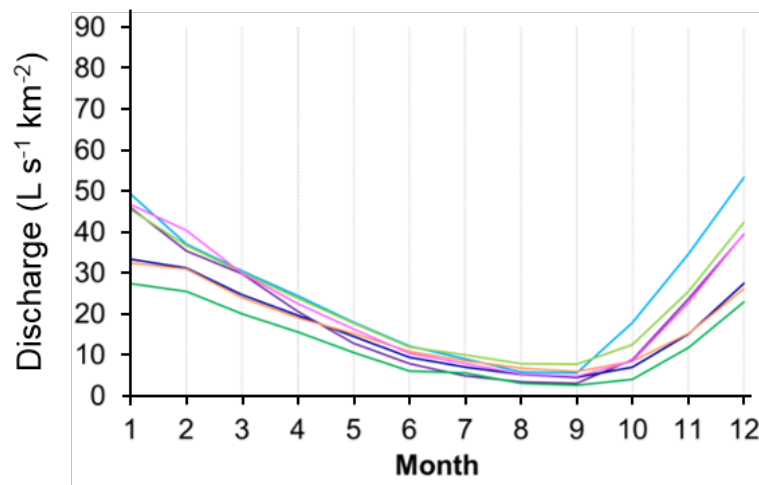

98 99

$-1-2-3-5-6-7-8-9-10-11-12-13$

9 Figure 8: Monthly mean observed concentrations of (a) $\mathrm{NO}_{3}{ }^{-}$, (b) $\mathrm{PO}_{4}{ }^{3-}$, (c) $\mathrm{DSi}$, and (d) monthly specific discharge. We observed two types of seasonal fluctuations: synchronous, where hydrology and nutrient concentration were in phase (annual peak concentration during high flow), and asynchronous, where hydrology and concentration are out of sync (annual minimum concentration during high flow). 
Asynchronous

a.

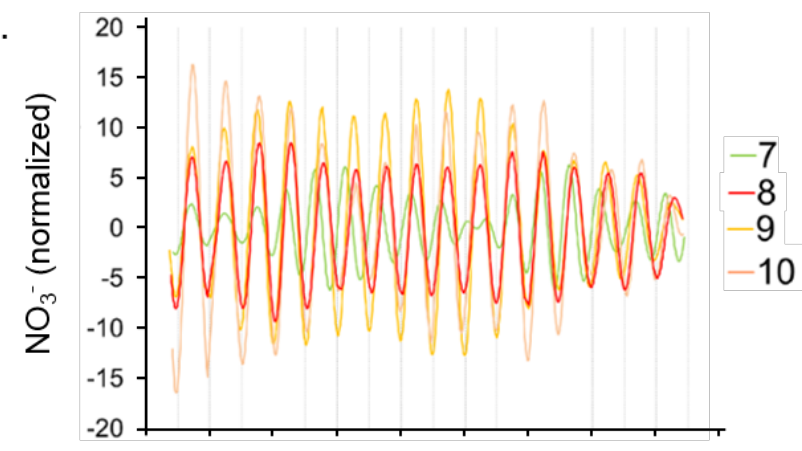

b.

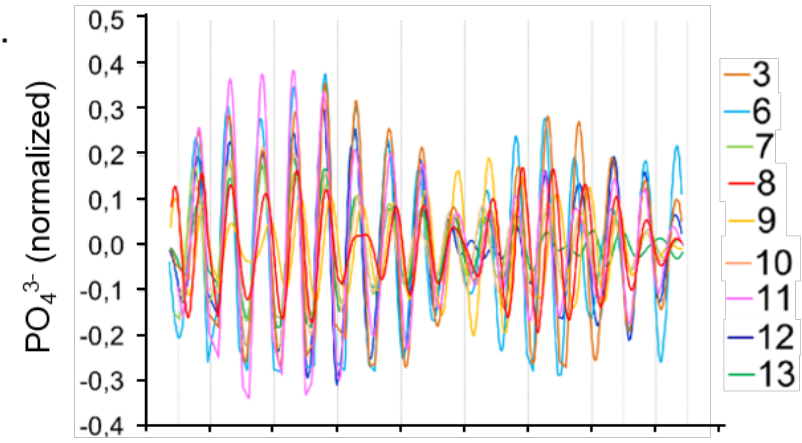

Synchronous

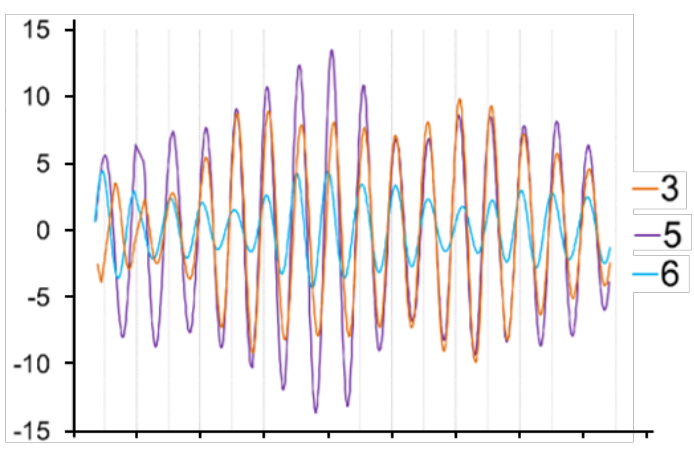

c.

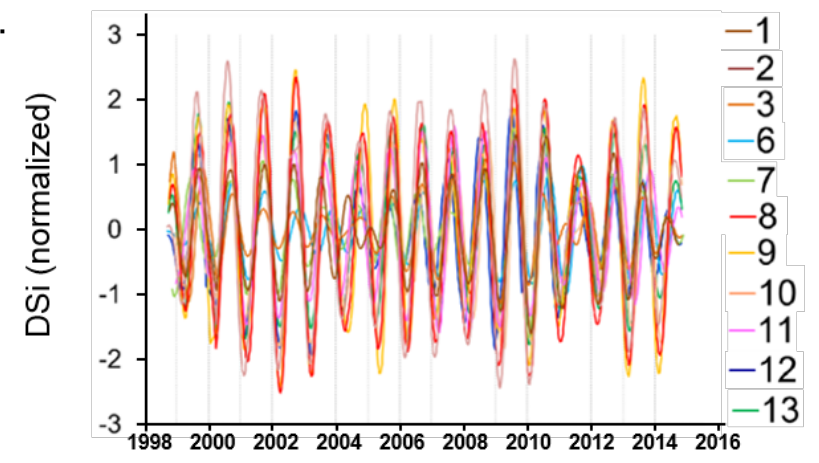

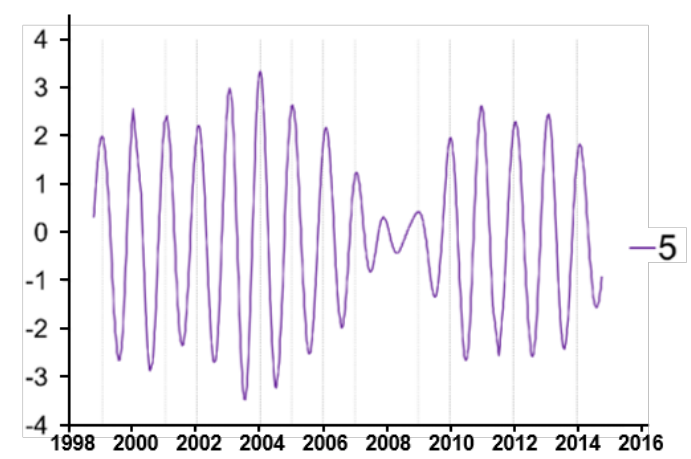

107 Figure 9. Long-term changes in seasonal nutrient fluctuations. Curves are the seasonal component of the variance partitioning models for $\mathrm{NO}_{3}^{-}$ (a), $\mathrm{PO}_{4}{ }^{3-}$ (b), and DSi (c). Time series were detrended and centered to facilitate comparison of changes in periodicity through time. Only rivers where at least $10 \%$ of the total variance was explained by the seasonal component are shown (Table 3). 